\title{
Revisão bibliográfica comentada dos fundamentos da Outorga Onerosa do Direito de Construir - OODC
}

\author{
Vera F. Rezende ${ }^{1}$, Fernanda Furtado ${ }^{2}$, M. Teresa \\ C. Oliveira e Pedro Jorgensen Jr. \\ Colaboração de Isabela Bacellar
}

\begin{abstract}
1. Introdução; 2. As principais referências internacionais; 3. A construção do conceito e a discussão no Brasil, uma revisão bibliográfica; 3.1. Justificativas, objetivos e potencialidades; 3.2. A formulação do conceito; 3.3. O debate jurídico: constitucionalidade, natureza e competências; 3.4. O necessário índice básico único e, até, unitário; 3.5. Outras questões relacionadas com a aplicação do instrumento; 3.6. Conseqüências possíveis da aplicação do instrumento; 4. O caminho em direção ao Estatuto da Cidade; 5. Comentários finais; 6. Notas; 7. Referências
\end{abstract}

\section{Resumo}

Este artigo contempla uma avaliação sobre as matrizes conceituais que orientaram a construção da noção da Outorga Onerosa do Direito de Construir, instrumento definido no Estatuto da Cidade para integrar a política urbana municipal das cidades brasileiras. Ao tratar deste poderoso e complexo instrumento de intervenção, e no sentido de melhor guiar sua aplicação nos diversos municípios, este trabalho propõe uma análise do longo caminho percorrido desde os primeiros debates até a edição de sua versão atual no Estatuto da Cidade, entendendo esta avaliação como necessária para uma melhor compreensão das potencialidades da outorga onerosa e das questões que permeiam os atuais debates sobre sua implementação. Para tanto, o trabalho realiza uma sistematização de extenso material bibliográfico que aborda o instrumento, assim como as questões pertinentes ao Solo Criado, conceito e instrumento que lhe dá origem, percorrendo as décadas de 70, 80 e 90. Com enfoque multidisciplinar, envolvendo aportes urbanísticos, jurídicos, econômicos e sociais, são abordadas variadas versões e entendimentos presentes nas justificativas para sua aplicação, nas formulações iniciais do conceito e em sua evolução, sendo ressaltadas as questões técnicas e políticas discutidas, e registrados os principais debates jurídicos ocorridos.

Palavras-chave: Outorga Onerosa do Direito de Construir; Solo Criado; Estatuto da Cidade; direitos de construir; instrumentos de política urbana.

\begin{abstract}
This paper analyzes the conceptual framework underlying the "Outorga Onerosa do Direito de Construir" (Public Concession of Building Rights), a legal instrument defined in the City Statute as part of urban policy in Brazilian municipalities. We analyze the evolution of this powerful and complex instrument from the early stages of its debate until its current version in the City Statute, emphasizing the importance of such analysis to the understanding of the procedure's potential and to the controversy on its implementation across different municipalities. With this intent, this paper
\end{abstract}


investigates the literature on the subject, as well as on a related concept, the "Solo Criado" (virtual land), from the seventies until the nineties. With a multidisciplinary approach, embracing urbanistic, legal, economic and social views, we analyze different reasons supporting its application, from the origins of the debate and during its evolution, with a special attention to technical and political issues, and registering the main legal controversies involved.

Key-Word. Granting the Right to Build Costly; Created Solo; City Statute; rights to build; urban policy instruments.

\section{Introdução}

O objetivo deste artigo ${ }^{3}$ é recuperar o caminho da construção teórica da noção de Outorga Onerosa do Direito de Construir e da discussão de sua possível prática, efetuando-se a revisão do material produzido sobre o tema ao longo das décadas de 70, 80 e 90 e destacando-se as questões principais que estiveram presentes ao longo dessas décadas. $\mathrm{O}$ material analisado contempla artigos, livros, conclusões de seminários e o conjunto da legislação proposta ou aprovada sobre o tema.

Embora a Outorga Onerosa do Direito de Construir (OODC) só apareça na normativa geral brasileira como instrumento de política urbana em 2001, através do Estatuto da Cidade, seus fundamentos remontam à década de 70 e, mesmo a sua aplicação se encontra prevista por municípios a partir do início da década de 90. O instrumento é inicialmente denominado Solo Criado (SC), denominação que evolui já na década de 90, quando de sua aplicação pelos municípios, para Outorga Onerosa do Direito de Construir, e que é consagrada pela Lei Federal no 10 257/ 2001.

Nos termos do Estatuto da Cidade, a OODC é definida da seguinte maneira: "o plano diretor poderá fixar áreas nas quais o direito de construir poderá ser exercido acima do coeficiente de aproveitamento básico adotado, mediante contrapartida a ser prestada pelo beneficiário." (art.28)

Com o objetivo de reconstruirmos a evolução do conceito de SC ou OODC, inicialmente, retornamos às referências internacionais, exemplos de utilização de instrumentos semelhantes ou que indiquem um maior controle sobre a terra urbana em outros países. Posteriormente, a partir da literatura produzida sobre o instrumento em questão, apresentamos a sua construção em seus contornos teóricos, as justificativas e potencialidades contempladas quando de sua proposição e os temas recorrentes que alimentam os debates e discussões técnicas por quase três décadas, empreendidos por estudiosos das cidades, juristas, 
economistas, arquitetos e urbanistas.

Alguns temas recorrentes são: a criação de solos adicionais e sua relação com a densidade dos bairros, a sobrecarga sobre a infra-estrutura urbana e a conseqüente necessidade de compensação dessa sobrecarga, e a necessária recuperação por parte do poder público da valorização da terra resultante do processo de urbanização em termos gerais.

Outras questões se encontram imbricadas nas formulações da noção, em que se destacam: a constitucionalidade do SC ou OODC, não só quanto à possibilidade de separação entre o direito de construir do direito de propriedade, mas também quanto à competência dos municípios para instituí-lo, a adoção de um índice básico único e até unitário para a aplicação do instrumento. Essas questões, entre outras, estão relatadas e relacionadas aos autores que compartilham determinadas posições como veremos a seguir.

Finalmente, ressaltamos os marcos que pontuam a proposição do instrumento do SC ou OODC, no período que vai do surgimento dos primeiros artigos de autores que o propõem à aprovação da Lei n ${ }^{\circ} 10$ 257/ 2001, o Estatuto da Cidade. Para tanto, destacamos nessa seção principalmente, documentos como a Carta de Embu ${ }^{4}$, e minutas, anteprojetos, projetos de lei ou leis que expressam a intenção de adoção de um maior controle sobre o solo urbano no período de estudo.

\section{As principais referências internacionais}

As primeiras experiências internacionais documentadas relacionadas com o Solo Criado revelam objetivos e contextos muito diversos e datam, na sua maioria, do início da década de 70. Todas, no entanto, se não separam diretamente o direito de construir do direito de propriedade, limitam e submetem o direito de construir ao interesse coletivo ou instituem a possibilidade de se transacionar ou transferir o direito de construir de um lote para outro através da transferência de potencial construtivo. Surgem como uma alternativa aos efeitos negativos da urbanização, a partir da constatação das limitações de outros instrumentos, em especial o zoneamento, no encaminhamento de soluções para os problemas das cidades.

A preocupação com um mecanismo semelhante ao Solo Criado é expressa inicialmente em 1971 em Roma, Itália, quando técnicos ligados à Comissão Econômica da 
Europa, das Nações Unidas, e especialistas em política de habitação, construção e planejamento urbano defendem em documento ser necessária a separação entre o direito de propriedade e o direito de construir. Argumentam que este "deve pertencer à coletividade e não pode ser admitido senão por concessão ou autorização administrativa a particulares”. (C.J. Arquitetura, 1977, p. 3)

Dentre as primeiras experiências internacionais, ganha destaque a experiência americana exemplificada no Plano para a cidade de Chicago ${ }^{5}$ (1973), que demonstra o uso de dois instrumentos: space adrift e zoning bonus. O primeiro (na tradução literal espaço flutuante) foi pensado como parte de uma política de preservação de imóveis culturais, em que se previa a transferência do potencial construtivo de um lote (que acomodasse um edifício histórico) para outro ou outros, com o objetivo de se compensar o proprietário do imóvel que se pretendia preservar quando da não utilização total do potencial construtivo permitido. No caso americano, esse direito de construir é passível de ser transacionado entre particulares (Costa e Santos, 1977; Costonis, 1974).

Embora a utilização desse instrumento previsse tão somente a transferência de potencial construtivo envolvendo lotes com imóveis a se preservar, já se identificavam algumas dificuldades legais quanto à sua aplicação. A primeira quanto à validade da desapropriação e revenda dos direitos de desenvolvimento em imóveis históricos, pois, embora existindo benefícios públicos, o beneficiário final não seria o público, mas alguns empreendedores que possuiriam os direitos de desenvolvimento. A segunda quanto à validade da obtenção e cumprimento das restrições de conservação e a terceira quanto à permissão aos possuidores de direitos de desenvolvimento para que construíssem edifícios maiores que os permitidos pelo zoneamento ${ }^{6}$ (Costonis, 1974).

O segundo instrumento (numa tradução literal bônus de zoneamento) previa a possibilidade de se permitir coeficientes de aproveitamento do solo maiores, e, portanto, mais lucrativos para os empreendedores, exigindo-se em contrapartida o financiamento de uma melhoria ou equipamento a critério do poder local (Costa e Santos, 1977). A crítica a este instrumento é a de que, diferentemente da transferência de potencial, onde só existia uma redistribuição de densidades já aprovadas pelo zoneamento, os bônus injetavam novos aumentos de densidade na comunidade, que se não fossem bem controlados, poderiam criar demandas por serviços públicos que a cidade não poderia atender. 
A experiência francesa foi provavelmente a que mais influenciou as primeiras experiências brasileiras. Em 1975, uma nova política fundiária e de reforma urbana é formulada na França, visando aumentar a eficácia de controle do uso e ocupação do solo; reduzir as desigualdades sociais decorrentes do zoneamento, que provoca a valorização diferenciada da terra; e aumentar a participação da coletividade no processo de planejamento, através da redistribuição de responsabilidades entre o Estado e as Comunas. (EMURB, 1977).

$\mathrm{Na}$ experiência francesa, o direito de construir acima de uma densidade construtiva básica só poderia ser obtido diretamente do Estado, havendo a possibilidade de transferência do coeficiente de ocupação do solo nos casos de imóveis tombados ou a preservar ou em áreas que justificassem a não urbanização. Define-se um teto legal de densidade (plafond légal de

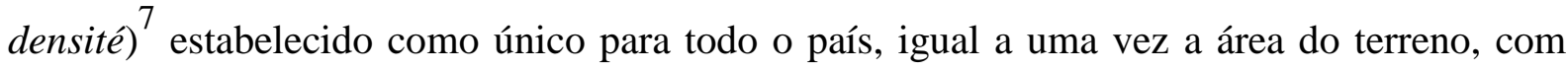
exceção de Paris, onde é fixado em uma vez e meia a área do terreno. Nos casos em que a legislação permita que esse limite seja ultrapassado, a edificação que exceder o teto é subordinada a um depósito pelo beneficiário, à Prefeitura, correspondente ao valor do metro quadrado do terreno, na proporção da área em excesso.

Ao PLD são atribuídos os objetivos concretos de luta contra a segregação social, através da redução dos preços fundiários, redução da densidade das áreas centrais e aumento dos recursos a nível local. Esses dois últimos contraditórios , segundo Granelle (1981), já que não se poderia obter um aumento dos recursos, a não ser que se promovesse o adensamento. De acordo com o mesmo autor, a intenção original seria dissociar o direito sobre o solo do direito sobre o espaço, intenção que não prevalece por razões constitucionais, adotando-se uma concepção fiscal.

Embora a sua análise inicial leve em conta um pequeno período de 5 anos, segundo ainda Granelle (1981), o PLD fez com que os incorporadores, em grande parte, se adequassem aos limites, optando por orientar as suas atividades para obras de recuperação de edificações em áreas centrais ou de novas construções na periferia. A conseqüência foi a geração de um pequeno volume de recursos para o poder público com a aplicação do instrumento.

Na França, na década de 80, o PLD é objeto de várias emendas, que acabam com a sua supressão na maioria dos municípios. Em 1992, no Seminário Solo Criado realizado no Rio de Janeiro, Granelle apresenta as modificações normativas ${ }^{8}$ que alteraram a aplicação do 
instrumento e avalia os seus efeitos após 16 anos de sua instituição: "Um efeito positivo é a tendência à redução dos preços da terra....e também a diminuição da diferença de preços centro-periferia. Talvez, o único efeito perverso que se possa citar do PLD seja a retenção da terra pelos proprietários no primeiro período de aplicação da lei.” (p.11)

Na Itália, o governo propõe, em 1975, uma lei que estabelece a separação do direito de construir do direito de propriedade. O direito de construir somente poderia ser exercido mediante concessão da Municipalidade ao proprietário da área, "o qual deve contribuir para as despesas necessárias ao agenciamento e equipamento da área”, exigindo-se o pagamento de uma determinada quantia como compensação. Fixa-se, também um prazo para a urbanização de certas áreas. (Costa e Santos, 1977, p. 92) As construções, portanto só poderiam ser realizadas de acordo com os objetivos traçados por Planos Plurianuais de atuação urbanística, elaborados pelas grandes comunas, que também determinariam os prazos para a urbanização das áreas (Costa e Santos, 1977; EMURB, 1977).

A proposta transforma-se na Lei $n^{\circ} 10 / 77$, que estabelece que a execução das obras resultantes de atividade que envolva transformação edilícia e urbanística do solo fica subordinada à concessão da administração local (art. $1^{\circ}$ ). Nesse caso, o direito de construir não mais se insere como uma manifestação natural do direito de propriedade, mas fica destacado desse último e passa a constituir uma concessão do Estado ${ }^{9}$. Na tramitação do projeto que resultou na lei surge, entretanto, a preocupação da constitucionalidade dessa restrição ao direito de construir. (Lira, 1981)

As primeiras decisões da Corte Suprema italiana consideram inconstitucionais alguns dispositivos da nova Lei, mas posteriormente decide-se sobre a constitucionalidade do instrumento e o ordenamento italiano passa a reconhecer uma posição inicial de propriedade do solo correspondente ao terreno sem capacidade de edificar ${ }^{10}$.

Outros exemplos de experiências internacionais que, de alguma forma, submetiam o direito de construir à coletividade também são descritos na literatura. A Grã Bretanha, já em 1947, aprova um dispositivo legal que prevê que os proprietários que detivessem uma autorização para construir deveriam pagar ao Estado ou à coletividade uma soma igual à totalidade das mais-valias que suas terras sofreriam em consequiência de obras públicas. Este dispositivo é abandonado no pós-guerra por ser considerado um freio ao desenvolvimento (Costa e Santos 1977). 
Na Espanha, para lidar com a escassez de terra urbanizada, já a partir da década de 50, procura-se forçar o aproveitamento de terrenos em áreas urbanizadas (“edificación forzosa”) (Lira, 1983). Posteriormente, na década de 70, a partir de Lei do Solo de 1975, busca -se resgatar parte das mais-valias urbanísticas sob a forma de solo edificável, que facilite a provisão das obras de infra-estrutura e equipamentos urbanos. Busca-se a possibilidade de dispor gratuitamente de todo o solo correspondente às infra -estruturas e aos equipamentos urbanos, pelo mecanismo de compensação em solo edificável. (Costa e Santos, 1977)

Em meados da década de 70, a Colômbia aprova uma lei que fixa, entre outros dispositivos de intervenção urbana, a extensão vertical da propriedade do solo urbano. A idéia subjacente é de que o domínio do espaço aéreo pertence à sociedade e a lei propõe uma limitação de altura inerente ao direito de propriedade, a partir da qual deverá ser o volume de construção adquirido das autoridades locais. Em vez de se pensar em criação de solo, é proposta uma limitação de altura, fazendo-se, assim, uso de uma dimensão física como elemento básico para a restrição.

Na década de 70, como vemos, a questão fundiária, expressa principalmente pela escassez de terra urbanizada e pela necessidade de controle sobre o aproveitamento da terra, já se encontra incluída entre as preocupações de diversos países. Como resultado, em 1976, a Conferência das Nações Unidas sobre os Assentamentos Humanos "Habitat", realizada em Vancouver no Canadá, contempla entre as suas conclusões, o princípio geral $\left(n^{\circ} 10\right)$ :

“A terra é um dos elementos fundamentais dos assentamentos humanos. Todo Esta do tem direito a tomar as medidas necessárias para manter sob fiscalização pública o uso, a propriedade, a disposição e a reserva de terras. Todo Estado tem direito a planejar e administrar a utilização do solo, que é um de seus recursos mais importantes, de maneira que o crescimento dos centros populacionais tanto urbanos como rurais se baseiem num plano amplo de utilização do solo. Essas medidas devem assegurar a realização dos objetivos básicos da reforma social e econômica para cada Nação, de conformidade com seu sistema e suas leis de propriedade da terra". (C. J. Arquitetura, 1977, p.4)

Reflexos da experiência internacional e como são tratadas as questões que fundamentam, especialmente, o Solo Criado ou outros instrumentos de controle da terra urbana, podem ser observados no Brasil. Alguns autores reproduzem exemplos e os discutem, 
destacam-se: Azevedo Netto (1977 a), que discute experiências similares nos EUA, na França e na Espanha: Maria de Lourdes C. Costa e Sergio Lordello dos Santos (1977), que apresentam as experiências de outros países no tratamento de questões relacionadas ao direito de construir e ao direito de propriedade na França, Grã-Bretanha, Itália, Suécia, Colômbia, Espanha e Estados Unidos.

Lira $(1983,1991)$ que nos relata o caso francês e, ainda, o caso espanhol da “edificación forzosa" prevista nas leis de 1956, 1975 e em decreto de 1976 sobre o Regime de Solo e Ordenação Urbana ${ }^{11}$, que caminham no sentido do estabelecimento de limites ao direito de construir. E, ainda, E. Azevedo e Mazzei de Alencar (1993), que apresentam exemplos dos EUA, França, Itália, Espanha ${ }^{12}$ e Suécia.

E, por fim, o próprio J. Granelle, que por duas ocasiões (1981, 1992a e 1992b), em artigos publicados ou divulgados no Brasil, apresenta e avalia a aplicação do PLD na França. A primeira vez (1981), quando das discussões que fundamentam o instrumento. A segunda vez (1992), quando da preparação dos Planos Diretores para os municípios de São Paulo e Rio de Janeiro.

As experiências estrangeiras certamente influenciaram o curso do debate no Brasil sobre o Solo Criado e suas variantes. No entanto, Azevedo Netto (1977) refuta a crítica de que o conceito seja importado, afirmando que o SC é um "conceito puramente brasileiro, nosso, paulista. Não foi importado, ninguém o encontrará em nenhum documento técnico, em nenhuma legislação do mundo todo" (p.44). Embora já existissem instrumentos que se utilizassem dos mesmos princípios, o termo solo criado e o conceito de criação do solo são pela primeira vez divulgados no trabalho de Moreira, De Ambrosis, Nogueira Filho e Azevedo Netto (1975). (Brasileiro, 1977)

\section{A construção do conceito e a discussão no Brasil, uma revisão bibliográfica}

Ao analisarmos a produção sobre o tema, sob a forma de artigos, propostas de leis ou conclusões de seminários, podemos perceber uma distinção entre aqueles produzidos nas décadas de 70 e 80 e os produzidos na década de 90. Os primeiros buscam principalmente justificar o instrumento, conceituá-lo e dirimir dúvidas quanto à sua constitucionalidade e à necessidade ou não de se considerar destacável o direito de construir do direito de 
propriedade para a sua aplicação.

Os textos produzidos na década de 90, após a Constituição de 88 , coincidem ou são imediatamente posteriores à previsão do instrumento em alguns planos diretores municipais. Com a tarefa de conceituação da OODC já efetuada pelos autores que os precedem, esses textos enfocam principalmente seus possíveis efeitos e mecanismos para a sua aplicação. Por essa razão, a nossa revisão ressalta essa periodização.

Uma avaliação sobre as matrizes conceituais no Brasil, que orientam a construção da noção da OODC, nos leva, portanto, inicialmente aos trabalhos que nas décadas de 70 e 80 se detiveram sobre o tema. Na maioria desses trabalhos, se encontra presente como ponto de partida a reflexão sobre o processo de adensamento e verticalização das cidades e a evidente impossibilidade de inclusão dos grupos de diversos níveis de renda na oferta de seus bens, entre eles a moradia e a infra-estrutura viária e de saneamento, a partir de instrumentos tradicionais de regulação urbana.

Nessa reflexão, o componente fundiário da urbanização sobressai como figura central a ser objeto necessariamente de outros instrumentos, que ultrapassem a tradicional atuação do poder local na distribuição de índices construtivos. Trata -se de caminhar além desse tipo de regulação, tomando por base a atuação federal na questão dos loteamentos, em que já são colocadas obrigações aos proprietários de terras com interesse em parcelá -las, anteriormente à Lei $n^{\circ}$ 6766/79. Dentro dessa perspectiva, obrigações colocadas para os proprietários, incorporadores ou empreendedores imobiliários interessados em construir, da mesma forma, por semelhança, se justificariam.

Não podemos deixar de mencionar que a idéia da utilização do Solo Criado como instrumento de controle do uso do solo começa a ser desenvolvida no Centro de Estudos e Pesquisas de Administração Municipal - CEPAM, atualmente Fundação Prefeito Faria Lima. O primeiro trabalho que utiliza a denominação vem a público em 1975 por autoria de Domingos Theodoro de Azevedo Netto, Antonio Cláudio Moreira Lima e Moreira, Clementina De Ambrosis e Daimo do Valle Nogueira. (Brasileiro, 1977)

A justificativa do Solo Criado, então, é principalmente a correção das injustiças causadas pelas leis de zoneamento e uma forma de intervenção deliberada do poder público sobre a terra, com vistas a reequilibrar o melhor atendimento das necessidades da 
comunidade.

\subsection{Justificativas, objetivos e potencialidades}

No elenco das justificativas para o instrumento, há uma concordância com diferentes nuances entre diversos autores. Embora, o debate sobre o instrumento nas décadas de 70 e 80 seja levado em grande parte pelas mãos de urbanistas e juristas.

Num primeiro conjunto de argumentos, é apontada a valorização diferenciada da terra que beneficia proprietários, resultante em grande parte de normas de uso e ocupação e investimentos públicos, justificando mecanismos que recuperem essa valorização para o poder público. Estabelecer uma maior justiça social entre proprietários, já que todos teriam o mesmo direito de construir, aparece como um dos objetivos. Nessa vertente estão os trabalhos e afirmações de Moreira Lima, Azevedo Netto, Ambrosis e Nogueira Filho (1975), Azevedo Neto, Moreira Lima, Ambrosis e Nogueira Filho (1977), novamente Azevedo Netto (1977a), Eurico Azevedo (entrevista apud Brasileiro, 1977) e Hori (1977).

Na década de 90, E. Azevedo e Mazzei de Alencar (1993) destacam para o instrumento a função de eqüidade social, assegurando igualdade de direitos de construir. Silva e Saule Jr. (1993) invocam a questão da justiça social, atribuindo ao instrumento um caráter redistributivo de rendas fundiárias, ao propor a distribuição, com eqüidade, dos custos e benefícios dos investimentos públicos.

Ribeiro e Cardoso (1991) justificam, além de sua potencialidade como gerador de recursos que, de forma compensatória, financiariam programas habitacionais e de urbanização de áreas populares, a sua função de diminuir significativamente a escassez social de terra urbanizada. Como parte integrante da política habitacional, o instrumento, segundo eles, desbloquearia a terra dos entraves que a empurram para a lógica especulativa e excludente em termos sociais.

A necessária subordinação do poder econômico ao interesse geral está expressa em Seabra Fagundes (1977), Fortuna (entrevista apud Brasileiro, 1977) e Moreira (1977). Hori (1977) o justifica também para compatibilizar o direito de propriedade com a função social da propriedade. 
Destacam-se, ainda, a verticalização e o adensamento das cidades, com resultados nefastos para a qualidade de vida e para a saturação dos serviços públicos e áreas livres e públicas. O Solo Criado se colocaria nessas situações para restaurar o reequilíbrio urbano, principalmente entre bens e serviços públicos por um lado e demanda por outro lado, conseqüentes do processo de adensamento. Encontram-se nessa linha os trabalhos e manifestações de Azevedo Netto e outros (1977), Mange (1977), Hori (1977), Contador (1977), Lira (1981, 1983), E. Azevedo (entrevista apud Brasileiro, 1977).

A justificativa para o Solo Criado baseada no que já é praticado em relação aos parcelamentos é afirmada inicialmente por Azevedo Netto e outros (1977), posteriormente por Contador (1977), Hori (1977) e Silva Cordeiro (1977). Fortuna (entrevista apud Brasileiro, 1977, p.90), também afirma:

"Do mesmo modo que o poder público exige normalmente dos loteadores a reserva de áreas para circulação e instalação de equipamentos, deve exigir do criador de solos superpostos a contrapartida para fazer face ao esforço do mesmo poder público no sentido de manter ou aumentar a qualidade de vida já existente."13

Também nessa linha está Campos Filho (1977), adicionando ao instrumento a função de uniformização dos preços do solo urbano em áreas legais e de redirecionamento de parte da poupança nacional. Junto com o IPTU progressivo, o instrumento traz, a seu ver, maior estabilidade e segurança para o mercado imobiliário. J Ferraz (entrevista apud Brasileiro, 1977), dentro dessa vertente, divisa no instrumento um papel regulador do mercado imobiliário.

Uma outra vertente de justificativas, ligada à anterior, enfoca diretamente a questão da carência de recursos públicos para atuar frente ao processo de urbanização. Nessa linha encontra-se a tese proposta em $1976^{14}$, com significativo impacto nos meios políticos e empresariais, pelo Prefeito de São Paulo, Olavo Setúbal, no XX Congresso Estadual de Municípios, em Guarujá.

Já na década de 80, estendendo-se pela de 90, pode-se observar o alerta de alguns autores quanto à multiplicidade e à incoerência de finalidades colocadas pela utilização do instrumento. J. Granelle $(1981,1992)$ destaca essa questão a respeito da sua utilização na França. Ribeiro e Cardoso (1991, p.59-60), aplicando a idéia para o caso brasileiro, advertem: 
"Se a principal finalidade buscada é a geração de recursos, não podemos pretender também que a aplicação do solo criado promova uma importante diminuição dos preços da terra. Se, por outro lado, busca-se o descongestionamento das zonas centrais, o solo criado, funcionando como inibidor da densificação construtiva, não pode pretender alcançar ao mesmo tempo a geração de recursos.”

\subsection{A formulação do conceito}

Em diversas ocasiões, seminários, simpósios, artigos de revistas, o tema é abordado, variando o enfoque dado ao Solo Criado e as opiniões a respeito de aspectos jurídicos e urbanísticos relacionados com o instrumento. Contudo, a revisão bibliográfica nos mostra que, embora expressa com diferentes palavras, existe uma relativa homogeneidade na formulação inicial do conceito:

"De um ponto de vista puramente técnico, toda vez que uma construção proporcionar uma área utilizável maior do que a área do terreno, haverá criação do solo. De um ponto de vista prático, poderá ser considerado como solo criado, a área construída que exceder uma certa proporção de área do terreno. Baseado neste conceito de solo criado podemos propor três novos instrumentos extremamente importantes para controle do uso do solo, a saber: coeficiente de aproveitamento único; transferência de direitos de construir; proporcionalidade entre áreas construídas e áreas de uso público.” (Azevedo Netto et al, 1977, p.9-10)

"A noção corrente de solo criado o considera uma figura jurídica mediante a qual limita-se a dimensão permitida de construção a um percentual da área do terreno, estabelecendo-se que a edificação acima do parâmetro somente será permitida desde que se dê a aquisição do respectivo direito de construir que seria alienado ao interessado por outro particular ou pelo Poder Público (na parte relativa a suas praças e áreas verdes).” (Grego, 1981, p.1)

“O instrumento do Solo Criado impõe a separação entre o Direito do Construir e o Direito de Propriedade. Assim, a edificação que exceder o(s) teto(s) de densidade pré-fixados só pode ser realizada através de pagamento de um tributo equivalente ao valor do metro quadrado do terreno em questão, na proporção da área construída em excesso.”(Cepam, 1982b, p.14) 
"Em sentido genérico, pode-se definir solo criado como sendo a criação de áreas adicionais de piso utilizável não apoiadas diretamente sobre o solo. É a criação de piso artificial. A idéia do solo criado pressupõe a adoção de um coeficiente único de apro veitamento do solo. É, partindo-se dessa idéia, que se pode chegar a uma concepção de solo criado strictu sensu, quando se terá que solo criado é o excesso de construção (piso utilizável) superior ao limite estabelecido em função do coeficiente único de aproveitamento." (Lira, 1983, p.6)

"Solo Criado: Estabelecer um potencial de edificação (que seria uma vez a área do terreno). O excedente (solo criado) seria vendido pelo Poder Público para sua utilização...

Solo Criado não é expropriação; pressupõe apenas uma limitação administrativa, dando ao Poder Público possibilidade de estimular ou desestimular a edificação, conforme o caso" (Seminário IDEPE ${ }^{15}, 1987$, p.139).

“...a questão do solo criado, colocado primeiramente como instrumento de política urbanística e depois como fonte direta ou indireta de receita ou redução de despesas. A idéia do solo criado - todo mundo conhece - se baseia fundamentalmente no estabelecimento de um potencial de edificação uniforme. Estabelecido esse potencial de edificação, que pode ser uma vez a área do terreno, o que passasse disso seria solo criado, ou seja, cada vez que se construísse, por exemplo, um andar, haveria criação de solo; havendo criação de solo, haveria necessidade de uma outorga do Poder Público, haveria possibilidade de cobrança por parte do Poder Público.” (Dallari in Seminário IDEPE, 1987, p.140)

Após a promulgação da Constituição Federal em 1988, o discurso sobre o instrumento passa a enfatizar a questão da recuperação para a coletividade dos benefícios que propicia para os fins de financiamento de infra-estrutura e serviços públicos:

"Trata-se de um mecanismo que permite a repartição entre proprietários da terra, incorporadores e poder público, dos benefícios privados do processo de urbanização criado pela iniciativa privada, mas que se funda no investimento que o conjunto da sociedade realiza na forma da implantação dos equipamentos e da infra-estrutura urbana. Ou seja, trata-se da apropriação, pela autoridade municipal, de parte da valorização fundiária e imobiliária."(Ribeiro e Cardoso, 1991, p.55)

"Permite que um proprietário construa acima de um índice de aproveitamento do 
terreno de sua propriedade. Neste caso, o Poder Público exige uma contrapartida em termos financeiros tendo em vista os benefícios que este proprietário irá auferir da infra -estrutura realizada pelo Poder Público. Ao estabelecer a diferenciação e os limites entre o direito de propriedade do solo e o direito de construir, os benefícios dos investimentos públicos em infra-estrutura passam a ser cobrados pelo Poder Público que os recupera para a coletividade, reinvestindo-os em equipamentos e serviços públicos. Esta outorga onerosa do direito de construir é também chamada de solo criado.” (Silva e Saule Jr., 1993, p.27)

“O solo criado é figura jurídica de natureza urbanística, mas que pode ser extremamente eficaz como meio de obtenção de recursos para obras e serviços públicos. A figura jurídica do solo criado representa a admissibilidade da dissociação do direito de construir do direito de propriedade, embora limitada a determinadas situações de interesse urbanístico" (E. Azevedo e Mazzei de Alencar, 1993, p.7).

\subsection{O debate jurídico: constitucionalidade, natureza e competências}

Surgem, das formulações acima, questões que se tornam pontos essenciais na discussão. Destacam-se, entre elas, as que envolvem explorações na doutrina jurídica, que justifiquem a separação ao menos parcial entre os direitos de propriedade e de construção, à luz da Constituição então vigente. A discussão sobre a constitucionalidade do instrumento pode ser encontrada em Grego (1981), que adota uma visão conjunta do interesse individual e do social, na delimitação dos direitos de propriedade. A cláusula da "função social” permitiria formas de controle da ação do responsável pela utilização do bem. Acima de determinado patamar, a decisão quanto ao uso do bem decorreria de uma co-decisão de que participariam poder público e proprietário, figura que pode ser estendida ao Solo Criado.

A possibilidade de separação do direito de construir do direto de propriedade, sem alteração do quadro constitucional vigente anterior à Constituição de 88, é vista como possível por Sergio Ferraz e Eurico Azevedo (apud Brasileiro, 1977), ressaltando este último a condição de que não seja esvaziado o seu valor econômico, ou seja, desde que assegurado um mínimo desse valor.

Segundo Lira (1981), em imóveis localizados em área urbana onde a possibilidade de construir constitui a essência econômica da propriedade, a simples autonomia do direito de 
construir, distinto do domínio e entregue ao Estado, conflitaria com a garantia constitucional da propriedade. A instituição do Solo Criado, segundo ele, no direito brasileiro, permite que se chegue a esse resultado sem criar problemas de inconstitucionalidade.

Seabra Fagundes (1977), contudo, não se alinha entre os que consideram a autonomia do direito de construir, ou seja, a possibilidade deste existir distinto do direito de propriedade. Para o autor, "em se tratando de imóvel localizado em área urbana, é na possibilidade de construir, via de regra que está a essência econômica da propriedade.” (p.58)

J. A. Silva (1981, p.313) ao afirmar que o instrumento não promove a separação do direito de propriedade do direito de construir, contudo o percebe como justificativa para a compensação de proprietários que não atinjam o índice único. Em suas palavras: "O conceito de solo criado, nos termos postos acima, não importa na separação da faculdade de construir do direito de propriedade do terreno. Ao contrário, reafirma-o na medida em que transforma em direito subjetivo a faculdade de construir até o limite do coeficiente único estabelecido. Tanto assim que, se a legislação de uso e ocupação do solo determinar para alguma zona ou área coeficiente menor, os proprietários terão direito a uma compensação pela limitação estabelecida em desigualdade com os demais proprietários."

Cabe aqui registrar o debate realizado no Seminário IDEPE (1987). Neste encontro J. C. Figueiredo Ferraz, ex-prefeito de São Paulo, sugere outros instrumentos e afirma :

"[O Solo Criado] É um instrumento inadequado, um instrumento prematuro, porque há outros meios de se arrecadar do que estar invadindo em conceitos clássicos e já consolidados pela sociedade brasileira, do que vem a ser um bem social. (...) No momento que extraio do indivíduo a capacidade de construir e tem que pagar se quiser transacionar com o governo, trocar etc., isso significa que lhe foi subtraído um direito. Isto é, na verdade, uma expropriação, nem é uma desapropriação." (Seminário IDEPE, 1987, p.146) ${ }^{16}$

Nessa ocasião, a comparação do Solo Criado com as obrigações impostas aos parcelamentos e a sua conseqüente constitucionalidade é lembrada por Malta. Ao discordar de Figueiredo Ferraz, afirma "é o mesmo instituto do loteamento, só que é loteamento do espaço aéreo.” (Seminário IDEPE, 1987, p.157)

Após a Constituição de 88, no momento de elaboração do Plano Diretor do Município 
de São Paulo, Eros Grau (1990a , p.9) afirma que não há no regime constitucional autonomia do direito de construir dissociado do direito de propriedade. Acresce, entretanto, que o exercício do direito de construir poderá ser definido em lei municipal. Quanto à competência para instituir o SC, Grau entende que o Município tem competência tanto para instituí -lo, quanto para instituir a transferência do direito de construir.

Também na década de 90, E. Azevedo e Mazzei de Alencar (1993, p.3), observam que:

“É possível afirmar, portanto, em face dos princípios constitucionais vigentes no Brasil, que o direito de construir pode ser dissociado do direito de propriedade, desde que tal providência tenha por objetivo o uso adequado do imóvel urbano de acordo com sua função no ordenamento da cidade e desde que essa providência não esvazie por completo o valor econômico da propriedade. Essa condução pode ser perfeitamente alcançada pela aplicação do solo criado."

Outros aspectos da construção do instrumento, que acionam, à época, debates jurídicos, dizem respeito à natureza do instrumento, se tributário ou não, e à competência municipal para instituí-lo na ausência de normativa federal. Embora a discussão sobre a natureza do instrumento não seja um tema recorrente, a questão está presente para vários autores até o início da década de 90, quando por ocasião da elaboração do Plano Diretor do Município de São Paulo, e também o do Rio de Janeiro, torna -se inadiável o aclaramento da questão.

É desse período a manifestação de Eros Grau (1990b, p.13), da qual reproduzimos o parágrafo a seguir e que orienta a aplicação do instrumento nesses planos diretores :

“Trata-se indubitavelmente, no caso, de um ônus, vínculo imposto à vontade do proprietário do imóvel como condição para a satisfação do seu próprio interesse e cujo descumprimento não importa a aplicação de sanção jurídica, mas tão somente efeitos econômicos negativos. Não há, pois, como confundir a obtenção da outorga onerosa de que se cuida com qualquer figura a que corresponda obrigação tributária."

O debate sobre a natureza já atravessava as décadas de 70 e 80. E. Azevedo (apud Brasileiro, 1977) apontava que no projeto do Conselho Nacional de Política Urbana - CNPU (1977), o Solo Criado se apresentava como uma licença especial remunerada, aproximando-se 
de um tributo, enquanto na proposta do CEPAM, este aparecia como uma compensação, à semelhança do que ocorre nos loteamentos, afastando-se das características de um tributo.

Greco Filho (1977) argumentava que a restrição do direito de construir a uma vez a área do terreno era admissível e tradicional, até no Direito brasileiro, que, inclusive, admitia restrição maior. Para o autor, contudo, a instituição de um valor a ser pago à Prefeitura ou ao Estado que correspondesse à efetiva transferência de direito de construir teria a configuração de tributo, insustentável em face da sistemática constitucional tributária vigente. Nessa afirmação o autor menciona especialmente a modalidade Solo Criado como transferência do direito de construir e não o Solo Criado como outorga onerosa do direito de construir (diferenças evidenciadas no Estatuto da Cidade).

O tratamento tributário como forma de instituição do instrumento era, ainda, considerado por G. Ataliba no próprio Seminário Cepam em junho de 1976 (apud Ferreira Junior, 1978), e também por Seabra Fagundes (1977) e Ferreira Junior (1978), enfocando este último autor somente o caso em que a compensação se desse por equivalente econômico (monetário). A compensação por doação de áreas vazias (de terreno) não apresentaria, a seu ver, características tributárias.

Ferraz (apud Brasileiro, 1977), ainda, não reconhecia a natureza tributária do instrumento, tratando-o como simples ampliação do poder de polícia em matéria de edificações. A par disso, pode-se verificar a utilização tácita do termo tributo, sem a conseqüente discussão da natureza do instrumento, como é o caso do documento de trabalho do Cepam (1982b).

Cabe destacar, também, o entendimento exposto pelo jurista Ives Gandra Martins, segundo o qual, o Solo Criado tem coloração tributária nítida ${ }^{17}$, sendo uma forma de tributação penal, "que visa desincentivar as construções, além de um determinado limite ou, em permitindo, impor elevado ônus, viabilizando acréscimo de receita aos cofres municipais" (1981, p. 62).

É, também, importante registrar aqui as discussões a respeito da competência municipal, na ausência de uma legislação federal que lhe desse apoio, questão ultrapassada através da regulamentação da Outorga Onerosa pelo Estatuto da Cidade. E. Azevedo e Sergio Ferraz (apud Brasileiro, 1977) se manifestam favoravelmente quanto à possibilidade de 
adoção do SC sem suporte de legislação federal. Eurico Azevedo impõe como condição, para que possa ser aplicado pelos municípios, que seja instituído nos mesmos moldes das exigências feitas aos loteadores, através de compensações com áreas livres correspondentes às áreas de solo criado.

Por outro lado, Seabra Fagundes (1977), embora, reconhecendo que a regulação do direito de construir é da órbita municipal, entende que caberia à União regular ou pelo menos permitir a negociabilidade do Solo Criado. Já para Greco Filho (1977), a definição do coeficiente básico e unitário (um) como atributo da propriedade lhe parecia matéria de Direito Civil e, portanto, de competência legislativa da União.

Naquele momento, para urbanistas como Adina Mera (apud Brasileiro, 1977), a evolução da proposta do município de São Bernardo do Campo, segundo ela correta do ponto de vista urbanístico, ao relacionar Solo Criado com áreas verdes, é esperada como um "balão de ensaio" a orientar futuras propostas em relação ao instrumento na questão da competência municipal.

\subsection{O necessário índice básico único e, até, unitário}

Nas formulações apresentadas, destaca-se, ainda, a questão da construção do conceito de Solo Criado apoiado necessariamente na adoção de um índice básico único.

A necessidade de fixação de um índice básico e único apresenta uma quase total unanimidade nos textos analisados, não se considerando a possibilidade de coexistirem índices básicos diferenciados numa mesma cidade como a forma adotada posteriormente pelo Estatuto da Cidade. Nesse caso, estão os trabalhos e entrevistas de Azevedo Netto e outros (1977), em que o coeficiente único poderia ser local, regional ou até valer para todo o país, Hori (1977), Mange (1977), E. Azevedo e Fortuna (entrevistas em Brasileiro, 1977), Jansen (1978) e Lira (1981,1986). A proposta do Prefeito O. Setúbal (1976) também adota essa posição.

Como já consta, em 1976, da Carta de Embu: “1- É constitucional a fixação, pelo Município, de um coeficiente único de edificação para todos os terrenos urbanos.1.1. A fixação desse coeficiente não interfere com a competência municipal para estabelecer índices diversos de utilização dos terrenos, tal como já se faz, mediante legislação de zoneamento.1.2. 
Toda edificação acima do coeficiente único é considerada solo criado, quer envolva ocupação de espaço aéreo, quer a de subsolo.”

A justificativa é apresentada de forma clara por Hori (1977, p.63): “O conceito de solo criado parte da idéia fundamental de que o direito de ocupar uma área urbana com construção deve ser igual para todos, incorporando-se ao direito de propriedade. Quer dizer: do ponto de vista jurídico, admite-se como inerente ao direito de propriedade um direito de construção igual para todos, que pode ser denominado coeficiente de aproveitamento único. Qualquer construção que reúna uma área de piso utilizável superior a esse coeficiente único configura criação de solo, devendo ser objeto de um ônus adicional para o proprietário."

E, também, Ferreira Junior, que se propõe a avaliar as versões existentes (1978, p.85): “Analisando as diversas versões do solo criado constatamos que todas coincidem quanto à necessidade de adoção de um coeficiente único de aproveitamento do lote do terreno, como condição prévia indispensável ao surgimento do adicional de solo. Divergem as sugestões no que tange aos encargos a serem impostos ao proprietário que quiser edificar acima desse coeficiente, e quanto à finalidade do conceito.”

O documento de trabalho do Cepam (1982b), contudo, é o único analisado em que encontramos a possibilidade de índices básicos diferenciados como alternativa ao índice único. Esse trabalho considera, ainda, a possibilidade de uma compensação para os proprietários que não atingissem o teto de densidade ou índice básico.

Além disso, a adoção de um coeficiente básico único e igual a um, constitui justificativa consistente na formulação do instrumento. Azevedo Netto (1977a, p.50) explica: "Esse valor foi, entre nós, quase por consenso admitido como igual a um (1). Intuitivamente seria a possibilidade de cobrir toda a extensão de um terreno; ou deixando-se recuos ou espaços para iluminação e ventilação, a construção poderia ter dois pavimentos conservando a mesma extensão da área construída."

O anteprojeto do CNPU, divulgado em 1977, afirma: “Art. 50. O proprietário tem o direito de construir em seu terreno área equivalente à do lote. $\S 1 .^{\circ}$ No solo urbano (art. $8 .^{\circ}$ ) em que houver conveniência de aumento populacional, lei municipal de uso e ocupação do solo poderá permitir construção de área excedente à prevista neste artigo, mediante licença da prefeitura.§ 2. ${ }^{\circ}$ A licença especial prevista neste artigo será sempre remunerada....” 
Abaixo desse valor igual a um, não se configuraria Solo Criado, entendimento que atenderia não só à garantia do não esvaziamento econômico da propriedade, assim como ao objetivo urbanístico de garantia de qualidade de vida e de aproveitamento racional da infra estrutura urbana. Acima desse coeficiente a criação de solos interferiria com o interesse da comunidade. Nessa linha estão os trabalhos de Hori (1977), Mange (1977), Contador (1977). E, também, a proposta apresentada por O. Setúbal (1976), o Plano de Desenvolvimento Integrado do Município de São Bernardo transformado em lei (1977) e a proposta para um projeto de lei para o município de São Paulo (1977) divulgada, mas não encaminhada à Câmara Municipal.

Para Greco Filho (1977, p.100) o índice básico igual a um está atrelado à possibilidade de construir, ao equilíbrio urbano e à transferência de potencial construtivo, ou seja, "quem quiser criar solo, construir acima da metragem quadrada de seu lote, deve adquirir de outrem esse direito, mediante transferência onerosa ou gratuita, de modo que, se a um terreno se incorpora ou se soma o direito de construir a mais, de outro esse direito é retirado, para que, afinal, a área de superfície urbana seja sempre igual à área construída.”

A respeito da variação do conteúdo econômico dos terrenos urbanos em função da aplicação de diferentes índices construtivos, assim se manifesta J. A. Silva (1981, p. 311):

"Pois bem, a fixação do coeficiente único iguala essa equação econômica. Esse coeficiente único pode ser qualquer um, mas o mais lógico e razoável consiste no coeficiente de aproveitamento correspondente a 1 (um), o que equivale a reconhecer a todo proprietário de terreno o direito de erguer nele uma construção correspondente, em metros quadrados, a tantos metros quadrados quantos ele tiver, ou seja, cada metro quadrado do terreno lhe dará o direito de construir um metro quadrado de edificação, coeficiente esse que poderá ser utilizado totalmente ou não, respeitados evidentemente os demais índices urbanísticos previstos para a zona."

Anos mais tarde, a respeito dos planos diretores após a Constituição de 88, o índice básico unitário e igual a um é também defendido por Somekh (1992b) a respeito do plano diretor para o município de São Paulo e por Cavallieri e Bezerra (1991) no caso do plano diretor do Rio de Janeiro, como vemos a seguir:

“A definição de um coeficiente de aproveitamento único para os terrenos visa a 
promover a igualdade na ocupação do espaço da cidade. A construção acima deste limite (1 para a zona urbana), nas Zonas Adensáveis, será concedida através da Outorga Onerosa do Direito de Construir, o Solo Criado, condicionada à existência de estoque na região.” (Somekh, 1992b, p.259)

"Os proprietários que desejarem ultrapassar o coeficiente 1 até o limite definido pela legislação, devem pagar à Prefeitura pela criação de solo. $O$ valor a ser pago decorre do próprio conceito definido no projeto de lei. Se o proprietário só tem direito, sem ônus, a criar um solo, para cada novo solo que ele criar, deve pagar o preço de um novo terreno. Essa é a idéia básica, ou seja, como se o proprietário precisasse "comprar" à Prefeitura um terreno adicional a cada solo que desejasse criar. Assim, todos os proprietários teriam o mesmo direito de construir e eliminar-se-ia a injustiça da extrema diferenciação de valor dos terrenos ser decorrente de um potencial construtivo que lhes é "doado", muitas vezes sem grande justificativa técnica, pelo Poder Público.” (Cavallieri e Bezerra,1991, p.267)

Em outro texto, Cavallieri (1994, p.383) relaciona, além disso, o índice básico igual a um à capacidade de infra-estrutura: "Como a possibilidade de criação de solo, através da construção vertical, depende da existência de infra-estrutura e equipamentos coletivos e, ao mesmo tempo, gera um aumento de demanda desses bens e serviços, o instrumento condiciona a construção acima do coeficiente 1 ao pagamento de uma contrapartida financeira ao Governo Municipal.”

\subsection{Outras questões relacionadas com a aplicação do instrumento}

Cabe registrar, a manifestação de Seabra Fagundes (1977), opondo-se à troca por pecúnia de áreas proporcionais às áreas criadas por construção, ou seja, de Solo Criado. A possibilidade de compensação em equivalente econômico é, contudo, considerada na Carta de Embu (1976) e também por Mange (1977) e Contador (1977), este defendendo o equivalente econômico pela inexistência de terrenos na mesma zona da construção ou pelo risco de aceitação de terrenos impróprios e, ainda, Grego (1981). Lira (1986), por outro lado, anos mais tarde, contempla o instrumento com duas versões: uma urbanística em que o criador de solo compensa a coletividade com a cessão de espaço em favor do grupo, e outra fina nceira, que pode ser tolerada, em que o criador de solo reverte à municipalidade uma certa importância em dinheiro. 
Autores se debruçam também sobre o processo de implementação do instrumento. A aplicação progressiva e contínua, que atinja a plenitude em 5 anos é defendida por Mange (1977). Smolka (1991) propõe o estabelecimento de um período de transição, na forma de moratória com prazo definido para terrenos adquiridos recentemente por edificadores e incorporadores, o que facilitaria a aceitação da proposta.

No momento de preparação do plano diretor do Rio de Janeiro, Cavallieri e Bezerra (1991) argumentam que conceder o tempo necessário à acomodação do mercado às novas regras é essencial para a aceitação do instrumento. O valor a ser pago aumentaria ano a ano, até que no quinto ano chegar-se-ia à cobrança de um terreno para cada Solo Criado. A relativização da fórmula pelo momento da cobrança estimularia os proprietários a edificarem o mais rápido possível e permitiria uma adequação gradual do valor dos terrenos ao valor da cobrança.

Outro ponto a considerar, segundo os mesmos autores, é a influência do preço da terra, em função da localização, sobre o valor a ser pago. Para atender a esse aspecto que resulta em valores bastante diversos para diferentes bairros, introduz-se na fórmula um mecanismo de correção, em função da localização do terreno combinada com o ano de pagamento do Solo Criado. Combinam-se, assim, variáveis para formar o redutor do Solo Criado, de modo a não provocar, no curto prazo, grandes impactos negativos no mercado imobiliário.

Para Somekh (1992a, p.25), a respeito do plano diretor de São Paulo, deve-se trabalhar com um "prazo de transição de 2 anos, para não penalizar os incorporadores que já tivessem comprado terrenos em zonas inflacionadas pelo potencial construtivo. Este dispositivo permite aos proprietários dos terrenos utilizá-los de acordo com o atual zoneamento, cujo potencial construtivo vai diminuindo $25 \%$ a cada 5 meses (Política do Bloco de Gelo)".

Outros se preocupam, como Ribeiro e Cardoso (1991, p.60-61) com a complexidade da implementação, que exigiria um efetivo acompanhamento: “... tendo em vista o caráter importante do instrumento, e seu papel na reestruturação dos mecanismos sociais de apropriação das valorizações fundiárias e imobiliárias, torna-se fundamental que sua aplicação seja acompanhada da implantação de um sistema de monitoramento e de gerenciamento eficaz. E, ainda, que todo o processo seja também desenvolvido sob controle da sociedade, através de conselhos com participação popular, permitindo assim uma real democracia da sua 
gestão."

Ou, como Smolka (1991, p.14) a respeito do plano diretor do Rio de Janeiro, com garantias para que o processo de aplicação do instrumento definisse previamente a forma de cálculo dos valores: "Finalmente caberia aprimorar a proposta no que tange a determinação dos valores base do metro quadrado para efeito de cálculo do solo criado, introduzindo ao mesmo tempo, as salvaguardas necessárias a que a fixação destes valores não seja objeto de negociações escusas e arbitrárias.”

\subsection{Conseqüências possíveis da aplicação do instrumento}

As consequiências do Solo Criado no mercado imobiliário fazem parte da discussão de sua construção e irão permear o debate até a década de 90. Contudo, há uma expressiva concordância sobre as consequiências do SC na queda dos preços dos terrenos já nas décadas de 70 e 80. Essa visão é compartilhada, entre muitos outros, por E. Azevedo (entrevista em Brasileiro, 1977) e por Mange (1977).

Apesar de admitir uma certa elasticidade no comportamento do mercado, esse último autor afirma que, se parece impossível que os preços dos terrenos baixem, pelo menos não subiriam. O repasse do valor do Solo Criado para o preço final das unidades, argumento muitas vezes levantado por profissionais do mercado imobiliário, não é considerado possível, a não ser em casos excepcionais de imóveis para os grupos de mais alta renda.

Segundo Campos Filho (1977), o custo do Solo Criado deverá ser absorvido por uma pequena redução da excessiva valorização dos terrenos urbanos e não pelo consumidor final da unidade imobiliária (apartamento ou escritório). Mas, para o Cepam (1982), a transferência do custo do SC para o proprietário do terreno ou para o consumidor final dependeria das condições do mercado de terras e de imóveis construídos.

Há nesse aspecto uma quase unanimidade entre os estudiosos sobre as consequiências do SC sobre o valor da terra, no longo prazo, salvo opiniões alarmistas e enviesadas pelos interesses de classe. Germanos (1977), refletindo a visão das empresas construtoras, vê o instrumento como mais um tributo, que irá incidir sobre o custo final das unidades, com efeitos no espraiamento das cidades, aumentando os custos do poder público com infra estrutura. Gomes de Almeida (entrevista apud Brasileiro, 1977), também, alerta para a baixa 
produtividade fiscal do instrumento e para os seus efeitos sobre o preço final das unidades.

Na década de 90, após a Constituição de 88, quando da elaboração e aprovação de planos diretores municipais, retoma-se o tema do SC e suas consequiências. Da mesma forma com o que acontece na discussão sobre a natureza do instrumento, há um caminho teórico percorrido e, ainda, uma aproximação quanto aos efeitos do SC sobre o preço dos terrenos. Nessa linha se destacam os trabalhos de Smolka (1991) e Ribeiro e Cardoso (1991 ):

Smolka (1991, p.3) afirma que "salvo em situações excepcionais de controle monopólico ou monopsônico do mercado de terras, o proprietário é, por assim dizer, inteiramente passivo na determinação do preço do terreno - vale dizer, ele é "price-taker" conforme convencionado na teoria econômica. O preço do terreno é determinado essencialmente pela concorrência (condição típica deste mercado) entre aqueles que disputam pelo uso do solo."

E, continua: “...qualquer tentativa do proprietário em repassar ao usuário o ônus de uma taxa sobre o valor do terreno, será inteiramente frustrada pelo mercado, conquanto as diferenças entre os terrenos não se alterem" (ibid). Conclui, afirmando que as inquietações dos incorporadores e construtores em geral são, em princípio, infundadas e devem ser atribuídas ao fato de que individualmente eles detêm parte significativa de seu capital imobilizado em terrenos ou a uma percepção equivocada de como opera o mercado imobiliário.

Para Ribeiro e Cardoso (1991, p.54-55): “... seu efeito mais geral e mais a longo é a diminuição do preço da terra, pelo aumento da oferta de solo urbanizado, a curto prazo, porque não alterará a rentabilidade da construção, pois o peso do pagamento do direito de construir não recairá sobre o lucro da construção."

A respeito da discussão do plano diretor para o Município de São Paulo, assim se manifesta Scherer (1992, p.48):

"Embora aparentemente a outorga onerosa do direito de construir seja o ponto mais polêmico do projeto, mesmo seus opositores mais fisiológicos sabem que ela é justa e que o mercado saberá acomodar-se a esta nova regra do jogo. Constitui na realidade um instrumento para estender o direito à cidade, a todos aqueles que pagam por este direito."

Outros efeitos relacionados com a adoção do Solo Criado são o virtual congelamento 
das áreas centrais mais valorizadas e o direcionamento da construção para as zonas mais periféricas, onde o preço da terra é menor e predomina a construção de edifícios com projetos que criem pouco solo. Nesta linha, na década de 90, estão os trabalhos de Ribeiro e Cardoso (1991) e outros, acompanhando o de J. Granelle (1992a) a respeito da França.

Outros, ainda, são apontados por Somekh (1992b, p.259), também a respeito do plano diretor para o município de São Paulo: "Um primeiro efeito esperado é a diminuição dos custos urbanização através da racionalização da ocupação da cidade. O estabelecimento de zonas adensáveis e dos estoques de área construída foram determinados pela existência de infra-estrutura passível de ser utilizada. Isto é, a um custo de investimento zero, os estoques representam a quantidade de área construída que a infra-estrutura suportaria hoje."

Quanto aos efeitos do instrumento para as camadas de mais baixa renda, assim se manifestam os estudiosos da cidade, sejam eles arquitetos, juristas ou sociólogos:

"A importância do instrumento para as camadas de mais baixa renda advém da possibilidade de o poder público obter maior área livre, que seria destinada ao lazer da população. Ou, então, a possibilidade de o poder público obter maiores recursos financeiros, que poderiam ser carreados para obras de infra-estrutura, em geral necessárias nos bairros periféricos ocupados por essa população. (E. Azevedo, entrevista em Brasileiro, 1977, p.94)

"O solo criado pode criar condições para que camadas de mais baixa renda tenham possibilidades de conseguir morar em áreas inseridas no tecido urbano e não tão-somente em áreas periféricas sem nenhum equipamento. O solo criado não é uma panacéia universal, mas, caso a carência habitacional (no sentido completo da palavra habitação) seja a mais importante ou de atendimento prioritário, o poder público - obtendo através do citado instrumento recursos vinculados a um fundo de reserva de áreas de habitação de interesse social poderia comprar terrenos em locais dotados de serviços de infra -estrutura.” (Mera, entrevista em Brasileiro, 1977, p.94)

“A instituição do solo criado carreará para o poder público terras ou recursos a serem aplicados em obras ou serviços ou na aquisição de terras, certamente a preços mais baixos, com o que poderá o poder público incentivar a implantação de habitação para as classes menos favorecidas.” (Fortuna, entrevista em Brasileiro, 1977, p.94)

Entretanto, Azevedo Netto, já em 1977, alerta para a crença excessiva nas 
possibilidades do Solo Criado para a solução de problemas sociais, inclusive a falta de moradias: “... o solo criado não é uma panacéia para curar todos os males da cidade, ou mesmo da nossa sociedade. Muitas vezes ao se discutir o solo criado ele é visto como solução para o problema de distribuição de riquezas ou para o problema da habitação das classes de menor renda. É preciso deixar claro que o conceito do solo criado não foi feito para isso, nem vai resolver todos os problemas urbanos. Vai resolver alguns, apenas alguns, mas muito importantes. Não dispensa o planejamento; pelo contrário, exige um bom pla nejamento." (p.54)

Na década de 90, Smolka (1991, p.10) adverte que o processo de implantação do Solo Criado "não é neutro em relação ao seu sucesso. Os ganhos e perdas devem ser claramente expostos e negociados de modo a reduzir, ao mínimo, eventuais expectativas alarmistas e de modo a evidenciar e/ou deixar transparecer possíveis atitudes anti-sociais dos agentes. $\mathrm{O}$ compromisso de utilizar, de imediato, boa parte dos recursos arrecadados com o solo criado, na contratação de novos empreendimentos habitacionais, para a população de baixa renda, pode ser um argumento valioso nesta negociação do próprio instrumento."

\section{O caminho em direção ao Estatuto da Cidade}

No Brasil, as discussões sobre a necessidade de meios efetivos de controle do solo urbano datam da década de 60. Em 1963, se realiza o Seminário de Habitação e Reforma Urbana - SHRU organizado pelo IAB, em Petrópolis, no Estado do Rio de Janeiro, no qual o quadro geral das cidades é discutido e é encaminhada a necessidade de instrumentos efetivos de controle do solo urbano. (França Leite, 1987)

A motivação é a necessidade de se equacionar uma política habitacional, que enfrente a crise nas metrópoles brasileiras. É proposto um imposto de habitação a incidir sobre terrenos e unidades com mais de $100 \mathrm{~m} 2$ que, porém, não se assemelha à OODC, assim como ainda não estão expressos no encontro entendimentos fundamentais do instrumento, como a valorização artificial de terrenos ou a questão da possibilidade de separação entre o direito de construir e o direito de propriedade.

Entretanto, constitui um avanço ao indicar a necessidade de estabelecimento de maiores limites ao direito de propriedade, além das limitações administrativas tradicionais, 
para o alcance de soluções para o problema habitacional ${ }^{18}$. Já se encontram nesse documento os princípios que, mais tarde, viriam a ser defendidos pelo Movimento Nacional pela Reforma Urbana na Assembléia Nacional Constituinte e, posteriormente, no contexto da elaboração do Estatuto da Cidade. (Bassul, 2005)

As primeiras idéias relacionadas com o instrumento do Solo Criado surgem em 1974, quando o Grupo Executivo da Grande São Paulo - GEGRAN, órgão da Secretaria do Planejamento do Estado de São Paulo, estuda, com a consultoria de Azevedo Netto, os problemas de uso do solo e suas possibilidades de controle, inclusive através de legislação específica. Como parte desse trabalho, em 1975, o GEGRAN realiza um seminário com a presença de juristas, em que são debatidos conceitos envolvidos na noção de Solo Criado, o direito de construir e o direito de criar solo. (Azevedo Netto, 1977a)

Em 1974, ainda, têm início no Município de São Bernardo do Campo estudos sobre o instrumento pela equipe técnica da Secretaria de Planejamento e Economia, tendo em vista verificar a possibilidade de inclusão do Solo Criado no conjunto das propostas urbanísticas do Plano em preparação. Em 1977, São Bernardo será o primeiro a ter este conceito transfor mado em lei através do Plano de Desenvolvimento Integrado do Município. A lei aprovada institui o coeficiente de aproveitamento 1 para toda a zona urbana e determina que o interessado em construir além desse limite deve pagar ao Município uma certa quantia por metro quadrado de área construída excedente. Os valores recolhidos com o Solo Criado são destinados a um Fundo de Áreas Verdes.

Em 1974, o então futuro governador do Estado de São Paulo, Paulo E. Martins, promove a realização de uma série de estudos preparatórios de seu governo e no relatório sobre o Controle do Uso do Solo, também sob a consultoria de Azevedo Netto, aparecem as propostas de fixação de coeficiente do aproveitamento único e da transferência de direito de construção. Nesse mesmo ano, o Solo Criado é discutido no Simpósio sobre Política Urba na, realizado em Brasília pela Fundação Milton Campos, tendo sido recomendado o seu estudo com vistas a sua aplicação em grandes cidades e em áreas metropolitanas. (Azevedo Netto, 1977a)

Em 1976, no XX Congresso Estadual dos Municípios em Guarujá, o Prefeito de São Paulo, Olavo E. Setúbal, propõe o Solo Criado como instrumento de uma "Política para Utilização do Solo Urbano", a ser criado a nível federal. A proposta consiste em assegurar a 
todos os proprietários de terrenos uma proporção fixa e uniforme de área construída e que esse direito de construir possa ser transferido a outros terrenos. Contempla a possibilidade de construção acima do limite fixado, mediante transferência dos direitos de construir de outros terrenos, ou aquisição dos direitos de criar solo, mediante concessão do Poder Público e a destinação dos recursos públicos provenientes da aquisição de direitos de construir, criando solo para aquisição de áreas públicas, para equipamentos comunitários ou reurbanização.

No mesmo ano de 1976, a questão do solo, onde se incluem as preocupações com a separação entre o direito de propriedade e o de construir, constitui o tema de três seminários realizados em São Sebastião, São Paulo e Embu em junho ${ }^{19}$ e dezembro de 1976, sob o patrocínio do Centro de Estudos e Pesquisas de Administração Municipal da Fundação Prefeito Faria Lima - CEPAM. Essa entidade, vinculada à Secretaria de Estado dos Negócios do Interior do Estado de São Paulo, constitui, sem dúvida, a que lidera ao longo do tempo os estudos e debates sobre o Solo Criado.

O resultado desses seminários é a Carta de Embu, datada de dezembro de 1976, um marco na evolução dos estudos sobre o tema. Os signatários da Carta são Álvaro Villaça Azevedo, Celso Antônio Bandeira de Mello, Dalmo do Valle Nogueira Filho, Eros Roberto Grau, Eurico de Andrade Azevedo, Fábio Fanucchi, José Afonso da Silva, Maria de Lourdes Cesarino Costa, Mario Pazzaglini Filho, Miguel Seabra Fagundes, Jorge Hori, Antonio Cláudio Moreira Lima, Clementina De Ambrosis, Domingos Theodoro de Azevedo Netto, Luis Carlos Costa e Norberto Amorim.

A Carta, nos seus "considerandos", admite de forma inovadora que, "assim como o loteador é obrigado a entregar ao Poder Público áreas destinadas ao sistema viário, equipamentos públicos e lazer, igualmente, o criador de solo deverá oferecer à coletividade as compensações necessárias ao reequilíbrio urbano reclamado pela criação de solo adicional."

Concluem, como vimos anteriormente, pela constitucionalidade da fixação pelo município de um coeficiente único de edificação para todos os terrenos urbanos, sem interferência com a competência municipal para estabelecer índices diversos de utilização dos terrenos, mediante legislação de zoneamento. Concluem, também, que o proprietário de imóvel sujeito a limitações administrativas, que impeçam a plena utilização do coeficiente único de edificação poderá alienar a parcela não utilizável do direito de construir. 
A separação do direito de propriedade e o de construir aparece pela primeira vez em nível nacional em 1977, através do instrumento do Solo Criado, na primeira versão do Anteprojeto de Lei de Desenvolvimento Urbano, elaborado pelo Conselho Nacional de Política Urbana - CNPU e publicado pelo Jornal da Tarde. O instrumento é proposto como um dos instrumentos urbanísticos, juntamente com a urbanização compulsória, destinada a coibir a especulação imobiliária.

$\mathrm{O}$ anteprojeto abriga a figura do Solo Criado (art. 50 e 51) ${ }^{20}$ e garante ao proprietário o direito de construir em seu terreno uma área equivalente à área do terreno; assegura ainda, mediante licença especial e remunerada, obedecendo a conveniências de natureza urbanística, a construção de área excedente. O instrumento, entretanto, gera reações contrárias e não é incluído no anteprojeto final, que dá origem ao Projeto de Lei Federal nº 775 de $1983 .^{21}$

O Projeto de Lei $n^{\circ} 775 / 83$, Projeto de Lei de Desenvolvimento Urbano, elaborado pelo Conselho Nacional de Desenvolvimento Urbano do Ministério do Interior, tenta estabelecer o perfil da propriedade em termos urbanísticos com a criação de instrumentos de controle e de limitação à utilização da propriedade, acarretando pressões de vários setores. Apesar de não conter o instrumento do SC, o projeto de lei inova quanto ao tratamento dado a vários temas e, em especial, fornece contornos urbanísticos ao direito de propriedade (Lira, 1983, Rocha Lagoa, 1984, Campos Filho, 1986), contemplando questões a serem observadas pelo planejamento urbano desde o nível federal até o municipal.

Na promoção do desenvolvimento urbano, as seguintes diretrizes, entre outras, devem ser observadas (art. $2^{\circ}$ ):“... IV - adequação da propriedade imobiliária urbana a sua função social, mediante: a) oportunidade de acesso à propriedade urbana e à moradia; b) justa distribuição dos benefícios e ônus decorrentes do processo de urbanização; c) correção das distorções da valorização da propriedade urbana; ... VIII - recuperação pelo Poder Público dos investimentos de que resulte a valorização dos imóveis urbanos;"

Constitui a primeira tentativa formal em nível nacional de tratar a questão da propriedade privada de maneira urbanística. A habitação fica incluída entre os serviços comuns de interesse metropolitano (art. 40). É proposta a criação de alguns instrumentos, entre eles o direito de superfície, o direito de preempção, o parcelamento, a edificação e a utilização compulsórias, o imposto predial e territorial progressivo e a transferência do direito de construir. 
Nos casos de ausência de plano, fica estabelecido para todos os lotes o índice de aproveitamento de terreno igual a 1, o que significa que o limite de área edificável por lote passa a corresponder à área de cada lote, determinação que vigoraria até a edição de um plano que definisse critérios locais. Os municípios sem tradição de planejamento ver -se-iam obrigados a elaborar um plano de uso do solo, para possibilitar uma ocupação mais intensa dos lotes. Ao mesmo tempo, consolida a idéia de um índice básico único e unitário.

A concessão da licença para construção fica sujeita ao Município, que pode concedê-la ou não, condicionando-a à existência ou à programação de equipamentos urbanos e comunitários $\left(\operatorname{art} .5^{\circ}\right)$. Esse artigo tenta modificar o direito de construir ao retirar do proprietário o poder de edificar segundo seu interesse pessoal.

Segundo Rocha Lagoa (1984), nesse projeto o Governo Federal mostra conhecer que a matéria urbanística depende de modo básico da disciplina conferida à propriedade. A seu ver, porém, existe uma nota de inconstitucionalidade no anteprojeto na série de artigos através dos quais se criam diretrizes a serem adotadas pelos municípios na elaboração das respectivas legislações urbanísticas, extrapolando-se a competência da União ${ }^{22}$.

O Projeto de Lei 775/73 causa inúmeras reações, principalmente por parte de representantes do setor de construção civil, e a inconstitucionalidade é por eles também argüida. Nesse caso, o aspecto denunciado se encontra relacionado aos limites colocados para a propriedade, e a definição do índice 1 para edificação em terrenos localizados em municípios que não possuam plano de uso e ocupação do solo. Essas alegações, como observa Rocha Lagoa (1984), não possuem fundamento, pois a Constituição já adotava o sistema pelo qual a propriedade era uma função social, sendo conferido ao proprietário um conjunto de deveres para a satisfação do interesse social.

Para a aprovação do Projeto de Lei Federal n 775/83, criam-se dificuldades. Por um lado, a reação dos conservadores pelas razões ligadas à questão do direito de construir, por outro lado, os municipalistas que condenam a intromissão da União na política urbana dos municípios. Em 1987, diante da proximidade da elaboração de nova Constituição, esse debate acaba por perder o sentido. Já estava de qualquer forma colocada a discussão sobre a separação do direito de construir do direito de propriedade.

No processo de preparação da nova Constituição, ganha força o Movimento Nacional 
pela Reforma Urbana, que retoma as propostas de instrumentos discutidos nas décadas de 70 e 80 e que, juntamente com setores progressistas da sociedade, influencia as disposições constitucionais. $\mathrm{O}$ direito à cidade e o direito à terra, bandeiras do movimento, se expressam nos conceitos de função social da cidade e função social da propriedade, este último já presente em textos constitucionais desde a Constituição de 1934. Entre esses mecanismos previstos para efetivar esses direitos se encontra o plano diretor obrigatório para cidades com mais de 20.000 habitantes.

Vários estudos (Ribeiro e Cardoso, 1991, Silva e Saule, 1993, Ribeiro e Santos Júnior, 1993, Maricato, 1994, Rolnik, 1994, Ribeiro, 1994, entre outros) contribuíram para uma melhor compreensão do que se denominou Movimento pela Reforma Urbana e quais os seus resultados para a Constituição de 88. Na fase de elaboração da Constituição, determinados princípios são traduzidos e consolidados numa emenda popular, síntese das reivindicações das discussões sobre a cidade ${ }^{23}$.

Um dos artigos da emenda contempla de forma conceitual, embora sem nomear, o instrumento do Solo Criado ou OODC:"A valorização de imóveis urbanos que não decorra de investimentos realizados no próprio imóvel, mas que seja proveniente de investimentos do poder público ou de terceiros poderá ser apropriada por via tributária ou outros meios" (apud Bassul, 2005).

Como resultado, ainda que nem todas as propostas da emenda popular ${ }^{24}$ sejam aprovadas, a Constituição de 1988 contempla um capítulo específico sobre política urbana, introduz a função social da cidade, reafirma o conceito de função social da propriedade e aumenta a responsabilidade dos municípios em formular e implementar a política urbana e a obrigação da preparação de planos diretores.

Ao estabelecer que a propriedade urbana cumpre sua função social quando atende às exigências fundamentais de ordenação da cidade expressas no plano diretor (art. 182 e art. 183), a Constituição Federal provoca, segundo M. Baldez (1991), um abrandamento formal na concepção e no caráter da propriedade privada e, segundo Lira (1991), traça um perfil que caracteriza a propriedade urbanística. A propriedade, a partir de 1988, fica submetida à política urbana determinada pelos municípios, sendo o Plano Diretor o instrumento privilegiado para a sua subordinação. 
Ao lado da antiga concepção de propriedade privada surge, então, a propriedade urbanística, como a denomina Lira (1986). Essa está condicionada à sua função social e tem origem na administração pública como agente do processo de produção da cidade. A cidade, nessa concepção, não é o resultado da atuação de proprietários no gozo de suas propriedades particulares, mas da própria administração na gerência do espaço urbano.

Porém, cabe destacar, como afirma Sonia Rabello ${ }^{25}$ (2003), que a concepção da função social da propriedade, instituída desde a Constituição de 1934, é somente fortalecida pela Constituição de 88, atuando sobre as interpretações em que se apóiam as decisões judiciais.

Com o final da Constituinte ${ }^{26}$ os estados e municípios preparam as suas Constituições Estaduais, Leis Orgânicas Municipais e Planos Diretores. As Leis Orgânicas, editadas após a Constituição de 88, ao contrário das leis anteriores que dispunham sobre aspectos burocráticos e administrativos, passam em geral a incorporar disposições relacionadas com o direito à cidade.

Várias leis orgânicas, como observam Silva e Saule (1993) prevêem a separação entre o direito de construir e o direito de propriedade, estabelecendo limites para esse último. Essa possibilidade de separação é colocada nas leis orgânicas de Vitória, Recife, Porto Alegre, Salvador, Florianópolis e Fortaleza.

O plano diretor passa então de plano físico territorial do passado à plano necessário à execução da política urbana. A proposta do Solo Criado é incluída em Leis Orgânicas e Planos Diretores de várias cidades do Brasil ${ }^{27}$, entre elas São Paulo, Rio de Janeiro, Niterói, Manaus, Santo André, Fortaleza, Campinas, Recife, Belém e Belo Horizonte.

Nas cidades do Rio de Janeiro e São Paulo, por exemplo, os planos propostos pelos Executivos Municipais incorporam os principais instrumentos que tratam das questões elencadas na Reforma Urbana, transferindo-se o processo de reação às propostas para o Legislativo. Esse processo é tão forte no caso do plano diretor de São Paulo que ele acaba por não ser aprovado. No Rio de Janeiro, a Lei Complementar $n^{\circ} 16 / 92$ aprova o plano diretor com modificações, que não chegam a desvirtuá-lo. O plano, entretanto, acaba por não ser regulamentado e aplicado. O instrumento do Solo Criado e a sua previsão nesses planos diretores foram abordados por autores como Cavallieri e Bezerra (1994), Cavallieri (1994) e Rezende (1995) a respeito do caso do Rio de Janeiro e Somekh (1991, 1992) e Scherer (1992) a respeito de São Paulo, entre outros. 
Quanto à regulamentação da política urbana constante da Constituição de 88 , vale mencionar que o projeto original do Estatuto da Cidade (Projeto de Lei do Senado ${ }^{\circ} 181$ de 1989) não menciona o Solo Criado nem o instrumento da Outorga Onerosa do Direito de Construir. Apenas orienta que o Plano Diretor Municipal - obrigatório para as cidades com mais de 20.000 habitantes - deve exigir (art.41, inciso VI) a prévia avaliação por parte dos órgãos competentes do Poder Público para a aprovação de quaisquer projetos de mudança de uso do solo, alteração de índices de aproveitamento, parcelamentos, remembramentos ou desmembramentos. (Furtado, 2005)

O projeto estabelece também que enquanto não for aprovado o Plano Diretor, o índice de aproveitamento máximo para construção será de uma vez a área do terreno. (Bassul, 2005). Neste particular, o projeto do Estatuto da Cidade segue a orientação dada pelo projeto de Lei 775/1983 (LDU), que estabelecia que no caso de ausência de um plano de uso do solo, todos os terrenos teriam índice 1,0 .

\section{Comentários finais}

A revisão da bibliografia do SC demonstra que a construção do instrumento foi feita paulatinamente, sempre suscitando muitos questionamentos até a formulação do instrumento OODC tal como previsto no Estatuto da Cidade. O próprio instrumento da OODC ainda levanta algumas questões importantes quanto à sua formulação e aplicação, principalmente quanto à adoção do coeficiente básico.

Este é um ponto crucial da discussão que merece ser aprofundado. Como afirma Rabello (2005, p.5) “... o índice básico se relaciona com o aproveitamento mais elementar do imóvel, o mínimo útil da propriedade, seu direito básico de utilização econômica, eqüitativamente atribuído, ao menos no seu aspecto econômico, aos proprietários das propriedades imobiliárias urbanas pelo poder público."

Embora nas formulações teóricas iniciais o índice único para toda a cidade fosse uma idéia central, na definição dada pelo EC o coeficiente básico passou a poder variar segundo áreas da cidade. Além disto, o coeficiente básico defendido originalmente era não somente único, mas de modo geral considerado igual a um, porque conceitualmente ele estava vinculado à construção de uma vez a área do terreno. Assim, qualquer construção acima da 
metragem da área total do terreno poderia caracterizar-se como criação de solo. Na prática, no entanto, o coeficiente básico é estabelecido localmente e, em poucos casos limita -se a um.

A concepção do SC como outorga de área construída acima de um coeficiente básico apresenta raízes conceituais comuns com o SC como transferência de potencial construtivo de um terreno para outro, o que dificulta a consideração de um instrumento de forma independente do outro. Melhor dizendo, as justificativas que fundamentam o SC no primeiro caso, tanto no que se refere a questões urbanísticas ligadas a densidades adequadas para determinadas áreas, como no que se refere à prevalência do interesse coletivo sobre o individual, são as mesmas que no segundo caso.

Além disso, as justificativas jurídicas que levam ao entendimento da possibilidade de separação parcial entre o direito de construir e o de propriedade e, ainda, a questão da constitucionalidade da criação do instrumento nas normas municipais ou federais, se constituem as mesmas. Nessa perspectiva, à vista da literatura produzida e de seus argumentos, consideramos que a aceitação de um deles como um instrumento de política urbana, inclui por extensão o outro, excetuadas demais questões relativas às dificuldades com a aplicação de cada um, que apresentam aspectos distintos, conforme ressaltado em outro trabalho deste grupo que trata da avaliação de experiências municipais (Furtado et al, 2006).

A Outorga Onerosa do Direito de Construir é um instrumento de intervenção poderoso e complexo. Muitos elementos ainda precisam ser investigados no sentido de melhor guiar sua aplicação nos diversos municípios, principalmente a respeito do real impacto de sua aplicação nos mercados fundiário e imobiliário, sua efetiva capacidade de recuperação de mais-valias fundiárias urbanas, sua interação com outros instrumentos que incidam sobre a valorização da terra e os eventuais riscos de distorções desses mercados.

Uma das dificuldades em relação à análise do instrumento é justamente a grande variedade de formas que ele adquire, propiciadas pelo Estatuto da Cidade, que transferiu para os municípios a definição sobre muitas das variáveis que incidem sobre a sua aplicação: coeficientes básicos, fórmula de cálculo, abrangência, definiç̧ão de contrapartidas, isenções, formas de gestão, destinação dos recursos e controle. Para os municípios, a Outorga Onerosa do Direito de Construir representa tanto uma conquista importante como instrumento de intervenção pública, como também, um grande desafio, exigindo uma melhor compreensão de 
seus limites para uma aplicação mais efetiva. 


\section{6 - Notas}

1

\begin{tabular}{|c|c|c|}
\hline $\begin{array}{l}\text { Professora } \\
\text { luminense }\end{array}$ & da & Universidade \\
\hline Professora & da & Universidade \\
\hline
\end{tabular}

Fluminense

3 Este artigo é fruto da pesquisa "Outorga

Onerosa do Direito de Construir, panorama e avaliação de experiências municipais realizada para o "Lincoln Institute of Land Policy", entre os anos de 2005 e 2006.

4

${ }^{4}$ Carta resultado dos três seminários realizados sob o patrocínio do Centro de Estudos e Pesquisas de Administração Municipal da Fundação Prefeito Faria Lima - CEPAM em 1976.

${ }^{5}$ Como modalidade de zoneamento, o Plano de Chicago propunha uma alteração no conceito de unidade de controle de desenvolvimento, tradicionalmente fixado no lote individual, para o distrito como um todo, possibilitando que lotes dentro de um mesmo distrito abrigassem densidades diferentes (Costonis, 1974).

${ }^{6}$ John Costonis vem algumas vezes ao Brasil para divulgar a experiência do Plano de Chicago e discutir os conceitos do solo criado, a convite do CEPAM com grande cobertura na mídia (Ver Folha de São Paulo, 26/06/76; O Estado de São Paulo, 03/03/77; Revista Projeto (45):22, nov.1982).

7

Na França, é instituído através da Lei $\mathrm{n}^{\circ} 75$ 1328 de 31/12/75 ("Code de l'Urbanisme") que limita a utilização do solo através do teto legal de densidade (art. 112).

${ }^{8}$ A Lei de 29/12/82 oferece, sobretudo aos municípios com mais de 50.000 habitantes, a possibilidade de aumentar o PLD até 2 (1,5 até

3 em Paris). A Lei de 18/07/1985 prevê que os Conselhos Municipais podem aumentar o PLD. Em 23/12/86, nova lei reforma fundamentalmente o PLD ao permitir sua revogação pelos municípios. O instrumento deixa de ser aplicado nos municípios que não se pronunciem por sua continuidade. (Granelle, 1992, p.6).

${ }^{9}$ Permanece, contudo, para uso do proprietário, uma densidade residual de $0,03 \%$ da área do terreno. Sobre o assunto ver Renard (1993). ${ }^{10}$ Esse princípio afirma-se, também, para fins
de desapropriação de um terreno, quando é
considerado o valor agrícola ou seja, o valor 
descolado da possibilidade de aproveitamento do terreno para fins urbanos (Lira, 1981).

${ }^{11}$ Lei de 12/05/56, Lei de 02/05/75 e Decreto de 09/04/76.

${ }^{12}$ Quanto ao caso espanhol, os autores ressaltam o Decreto $^{\circ} 1$ de 26/06/1992 (art. 6 e 8), que dispõe que a utilização do solo, sua urbanização e edificação, deverá ser observada com rigorosa observância das limitações que a lei urbanística estabeleça, sem qualquer indenização ao proprietário, salvo casos estabelecidos em lei.

${ }^{13}$ Essa afirmação assemelha-se ao princípio geral que antecede as conclusões da Carta de Embu (1976).

${ }^{14}$ Trata-se do trabalho denominado "Uma política para utilização do solo urbano" de 1976 reproduzido na CJ Arquitetura, 1977.

15 Seminário IDEPE (1987), integrantes: Geraldo Ataliba, Adilson Abreu Dallari, Luiz Célio Bottura, José Carlos de Figueiredo Ferraz, Luiz Gonzaga Mendes de Almeida, Aires Fernandino Barreto, Eurico Andrade Azevedo, Nelson Gomes Teixeira, Roberto Cerqueira César, Cândido Malta Campos Filho e Mário Eduardo Duarte Garcia.

A esse respeito, ainda, cabe lembrar as discussões em início da década de 90, no momento de preparação do plano diretor para o município do Rio de Janeiro em que o Solo Criado era visto pelos empresários como

"confisco de direitos líquidos e certos sobre suas propriedades", conforme citado em Cavalieri e Bezerra (1991).

${ }^{17}$ Segundo Gandra, “qualquer exigência para que se permita a construção além de certos limites ganharia , pela definição do art, $3^{\circ}$ do Código Tributário Nacional, coloração nítida e inequívoca de tributação”. (1981, p. 62)

${ }^{18}$ Com base nessas propostas, o governo João Goulart elabora um projeto de lei com o objetivo de criar o Conselho de Política Urbana (Copurb), com amplos poderes, de caráter consultivo, deliberativo e propositivo (Bassul, 2005).

19 Em junho de 1976, o CEPAM realizou o Seminário de São Sebastião (depois em São Paulo), que contou com a participação de especialistas Internacionais, como o Prof. John Costonis, jurista da Universidade de Chicago, o arquiteto Luís Gay Llacer, do Instituto de 
Estudos de Administração Local de Madrid e o Senador Jorge Cárdenas, da Colômbia. A presença desses especialistas devia-se ao fato de que em seus países os instrumentos da transferência dos direitos de construir e o coeficiente único já tinham sido aplicados (Azevedo Netto, 1977a).

20 "Art. 50. O proprietário tem o direito de construir em seu terreno área equivalente à do lote.

$\S 1 .^{\circ}$ No solo urbano (art. $8 .^{\circ}$ ) em que houver conveniência de aumento populacional, lei municipal de uso e ocupação do solo por construção de área excedente à prevista neste artigo, mediante licença da prefeitura.

$\S 2 .^{\circ}$ A licença especial prevista neste artigo será sempre remunerada, atendidas as disposições desta lei e as normas estaduais pertinentes.

...

§ 4." A remuneração da licença especial, para construção de área até duas vezes a do lote, pertencerá integralmente ao município, sendo o restante destinado ao Fundo Estadual de Desenvolvimento Urbano, instituído e regulamentado por legislação própria de cada estado.

Art. 51. O município não poderá expedir licença especial para a área excedente à do lote,

enquanto não tiver lei municipal regulando a ocupação do solo urbano, sob pena de nulidade, conforme o previsto no art. 54."

Posteriormente, em 1982, é também divulgado novo anteprojeto, desta feita do Conselho Nacional de Desenvolvimento Urbano- CNDU, pelo Jornal da Tarde de São Paulo, em que não está prevista a instituição do solo criado.

${ }^{22}$ A favor da inconstitucionalidade, existia o fato de ter sido apresentada uma proposta de Emenda à Constituição no 19/77, dando à União o poder de emitir normas gerais sobre o desenvolvimento urbano, projeto que havia sido rejeitado. (ROCHA LAGOA, 1984, p. 02 e 05).

23 Durante a tramitação e aprovação da emenda popular é criado o Fórum de Reforma Urbana, que agrupa o conjunto de propostas do período pré-constitucional. Esse fórum contém várias entidades e órgãos de pesquisa na área urbana.

${ }^{24}$ Não foram aprovados o imposto sobre a valorização imobiliária e a desvinculação do direito de propriedade do direito de construir. Alguns instrumentos foram enfraquecidos, 
como a desapropriação por interesse social e as penalidades para os terrenos ociosos.

${ }^{25}$ Consulta realizada a Sonia Rabello por Vera F. Rezende em junho de 2003.

${ }^{26}$ Após a promulgação da Carta, entidades organizam o I Forum Nacional da Reforma Urbana (1988), para a definição de formas de atuação. Posteriormente, são realizados os II, III e IV Fórum Nacional, este último realizado durante a Eco-92 no Rio de Janeiro.

${ }^{27}$ RIBEIRO, L. C .Q. et al., p. B21, 1994. 


\section{Referências}

AZEVEDO NETTO, Domingos Theodoro. Experiências similares ao solo criado. C. $J$. Arquitetura, Revista de Arquitetura, planejamento e construção, $\mathrm{n}^{\circ}$ 16. São Paulo: FC Editora, 1977a.

A eliminação do imposto predial. C. J. Arquitetura, Revista de Arquitetura, planejamento e construção, $\mathrm{n}^{\circ}$ 16. São Paulo: FC Editora, 1977b.

AZEVEDO NETTO, Domingos Theodoro et al. O 'solo criado'. C. J. Arquitetura, Revista de Arquitetura, planejamento e construção, $\mathrm{n}^{\circ} 16$. São Paulo: FC Editora, 1977.

AZEVEDO, Eurico de Andrade e Maria Lucia Mazzei de Alencar. Solo Criado. Seminário Avaliação dos instrumentos de intervenção urbana. São Paulo: FAUUSP, 1993.

BALDEZ, Miguel L. Solo urbano, reforma, propostas para a Constituinte. Revista de Direito da Procuradoria Geral. Rio de Janeiro, $\mathrm{n}^{\circ} 38$, 1986.

Conselhos populares e usucapião especial urbano. Centro de Defesa dos Direitos Humanos - CDDH, Petrópolis, 1991.

BASSUL, José Roberto. Estatuto da Cidade. Quem ganhou? Quem perdeu? Brasília: Senado Federal, Subsecretaria de Edições Técnicas, 2005.

BRASILEIRO, Ana Maria. O Uso do Solo "Criado", In Revista de Administração Municipal. Rio de Janeiro, n² 24, set/out 1977.

CÂMARA DE DEPUTADOS. Estatuto $d a$ Cidade. Guia para implementação pelos municípios e cidadãos: Lei $\mathrm{n}^{\circ} 10257$, de 10 e julho de 2001, que estabelece diretrizes gerais 
da política urbana $-2^{\circ}$ ed - Brasília: Câmara dos Deputados, Coordenação de Publicações, 2002.

CAMPOS FILHO, Cândido Malta. Argumentos em favor do solo criado. C. J. Arquitetura, Revista de Arquitetura, planejamento e construção, no 16. São Paulo: FC Editora, 1977. Instrumentos de política urbana frente à questão habitacional. Seminário de trabalho sobre política habitacional na grande metrópole. São Paulo: Fundap, 1985.

Comentário sobre o projeto de Lei Federal de Desenvolvimento Urbano, Espaço e Debates, n² (18), 1986.

Cidades Brasileiras: seu controle ou o caos: o que os cidadãos brasileiros devem fazer para a humanização das cidades. São Paulo: Nobel, 1989.

Carta do Embu. C. J. Arquitetura, Revista de Arquitetura, planejamento e construção, $\mathrm{n}^{\circ} 16$. São Paulo: FC Editora, 1977.

CAVALLIERI, Paulo Fernando. O Solo Criado e o plano diretor do Rio de Janeiro. Seminário Solo Criado, seu impacto na dinâmica urbana e os desafios para sua operacionalização, Prefeitura da Cidade do Rio de Janeiro. Rio de Janeiro, novembro 1992.

Plano Diretor de 1992 da Cidade do Rio de Janeiro: possibilidades e limites da reforma urbana. In RIBEIRO, Luís Cesar de Queiroz e Orlando dos Santos Júnior (orgs.).

Globalização, fragmentação e reforma urbana. Rio de Janeiro: Civilização Brasileira, 1994.

CAVALLIERI, Paulo Fernando e Márcia
Bezerra. O solo criado e o plano diretor do Rio de Janeiro. In RIBEIRO, Luiz Cesar de Queiroz e Luciana Corrêa do Lago (orgs.) Acumulação 
urbana $e$ a cidade. Rio de Janeiro: Rio de Janeiro, n 129, julho/set, 1977.

IPPUR/UFRJ, 1992.

CJ ARQUITETURA. O anteprojeto da lei de desenvolvimento urbano. C. J. Arquitetura, Revista de Arquitetura, planejamento $e$ construção, no 16. São Paulo: FC Editora, 1977. Memorando. C. J. Arquitetura, Revista de Arquitetura, planejamento e construção, $\mathrm{n}^{\circ}$ 16. São Paulo: FC Editora, 1977.

CONTADOR, José Celso. Um modelo para propiciar equilíbrio urbano. C. J. Arquitetura, Revista de Arquitetura, planejamento $e$ construção, nº 16. São Paulo: FC Editora,1977.

COSTA, Maria de Lourdes e Sérgio Lordello dos Santos. As experiências estrangeiras. C.J Arquitetura, Revista de Arquitetura, planejamento e construção, $\mathrm{n}^{\circ}$ 16. São Paulo: FC Editora, 1977.

COSTONIS, John. Plano de Chicago - "Space Adrift". Empresa Municipal de Urbanização.

SOLO CRIADO Análise das Experiências Estrangeiras EMURB/COGEP, São Paulo, 1977.

DORNELAS, Henrique Lopes. O Instrumento Jurídico da Outorga Onerosa do Direito de Construir (Solo Criado). Dissertação de Mestrado em Direito, UERJ, Rio de Janeiro, 2004.

EMPRESA MUNICIPAL DE URBANIZAÇÃO. Solo Criado: Análise das Experiências Estrangeiras. EMURB/COGEP, São Paulo, 1977.

FAGUNDES, M. Seabra. Aspectos jurídicos do solo criado. Revista de Direito Administrativo. 
FERREIRA JUNIOR, Letácio de Medeiros Belém: UFPA, 2007.

Jansen. Solo Criado. Revista de Direito da Procuradoria Geral do Rio de Janeiro, 33, Rio de Janeiro, 1978.

FUNDAÇÃO PREFEITO FARIA LIMA CEPAM. Carta do Embu. Documento Síntese do Seminário Aspectos Jurídicos do Solo Criado, Embu, SP, dezembro de 1976.

Instrumentos para aplicação de uma política fundiária urbana, sinopse do projeto, II Seminário de Problemas Fundiários Urbanos, Brasília, setembro 1982a.

Pesquisas sobre o problema fundiário urbano, documento de trabalho, São Paulo, 1982b.

FURTADO, Fernanda. Recuperação de Maisvalias Fundiárias Urbanas na América Latina: debilidade na implementação, ambigüidades na interpretação. Tese de Doutorado, FAUUSP, São Paulo, 1999.

—. Valorização do Solo Urbano $e$ Adequação de Instrumentos de Intervenção: aplicando os preceitos do Estatuto da Cidade.

Apresentado no X Encontro Nacional da Anpur, maio de 2003, Belo Horizonte, disponível em CD-rom.

Gestão Social da Valorização da Terra através do "Solo Criado": bases para o mapeamento das questões envolvidas.(versão preliminar - maio de 2005)

FURTADO, Fernanda, Vera F. Rezende, M.

Teresa C. Oliveira e P. Jorgensen. Outorga Onerosa do Direito de Construir, panorama e avaliação de experiências municipais. XII Encontro Nacional da ANPUR, 2007, 
GERMANOS, Paulo André Jorge. A visão das empresas construtoras. C. J. Arquitetura, Revista de Arquitetura, planejamento e construção, no 16. São Paulo: FC Editora, 1977.

GRANELLE, Jean Jacques. A Experiência francesa do teto legal de densidade, Seminário Solo Criado, seu impacto na dinâmica urbana e os desafios para sua operacionalização, Prefeitura da Cidade do Rio de Janeiro. Rio de Janeiro, novembro 1992a.

As experiências da política fundiária na França. In Direito do urbanismo, uma visão sócio-jurídica. Álvaro Pessoa (org.) Rio de Janeiro: IBAM, 1981.

L'expérience française du plafond légal de densité. Paris: ADEF, abril 1992b. (mimeo)

GRAU, Eros Roberto. Questões sobre o plano diretor, Faculdade de Direito - USP, São Paulo, 1990a. (mimeo)

A outorga onerosa do plano diretor de São Paulo: ônus e não obrigação, Faculdade de Direito - USP. São Paulo, 1990. (mimeo)

Emendas ao projeto de lei sobre o plano diretor. São Paulo: Faculdade de DireitoUSP, 1990b.

GRECO FILHO, Vicente. Sobre a constitucionalidade do solo criado. C. J. Arquitetura, Revista de Arquitetura, planejamento e construção, $\mathrm{n}^{\circ}$ 16. São Paulo: FC Editora, 1977.

GREGO, Marco Aurélio. O solo criado e a questão fundiária, In Álvaro Pessoa (org.),

Direito do Urbanismo, uma visão sóciojurídica. Rio de Janeiro: IBAM, 1981.
HORI, Jorge. Efeitos econômicos da implantação do solo criado. C. J. Arquitetura, 
Revista de Arquitetura, planejamento e Rio de Janeiro, 1986. construção, no 16. São Paulo: FC Editora, 1977.

INSTITUTO INTERNACIONAL DE DIREITO PÚBLICO E EMPRESARIALIDEPE. Seminário Solo Criado, conferências e debates. Revista de Direito Público, 1987.

IAB Departamento de São Paulo. As duas manifestações do IAB/SP C. J. Arquitetura, Revista de Arquitetura, planejamento $e$ construção, no 16. São Paulo: FC Editora, 1977.

Lei Orgânica do Município do Rio de Janeiro. Diário da Câmara Municipal do Rio de Janeiro, Rio de Janeiro, Edição Especial, Ano I, n 104 , 5 de abril de 1990.

LEITE, Vera França. Aspectos institucionais do desenvolvimento urbano - legislação federal para o desenvolvimento urbano, uma análise crítica do Projeto de Lei Federal 775/83. Dissertação de Mestrado, UNB, 1987. (mimeo).

LIRA, Ricardo Pereira. Liberdade e direito à terra. Revista de Administração Municipal, Rio de Janeiro, jan/mar 1981.

- Uso do solo urbano, utilização compulsória, direito de superfície. Revista de Direito Administrativo, Rio de Janeiro, vol. 148, abril/jun, 1982.

O uso do solo e o seu controle, Alguns Aspectos de Lei Federal $n^{\circ} 775 / 83$, Revista de Direito Administrativo, Rio de Janeiro, vol. 154, out/dez, 1983.

Disciplina do uso solo urbano, a propriedade urbanística, In Os Temas Fundamentais do Direito Brasileiro nos Anos 80. Rio de Janeiro: Universidade do Estado do 
- Campo e cidade no ordenamento
jurídico $\quad$ brasileiro, Conferência na Universidade degli Studi di Macerata, Italia, 1991. Rio de Janeiro: Riex Eds, 1991.

MANGE, Ernest Robert de Carvalho. O solo não é a terra. C. J. Arquitetura, Revista de Arquitetura, planejamento e construção, no 16. São Paulo: FC Editora, 1977.

MARICATO, Ermínia. Reforma urbana: limites e possibilidades, uma trajetória incompleta In RIBEIRO, Luiz Cesar de Queiroz e Orlando dos Santos Júnior (orgs.). Globalização, fragmentação e reforma urbana. Rio de Janeiro: Civilização Brasileira, 1994.

Habitação e as políticas fundiária, urbana e ambiental, diagnóstico $e$ recomendações. Texto preparatório para a reunião do Habitat, Rio de Janeiro, maio de 1995.

MARTINS, Ives Gandra. Solo Criado. Revista de Direito Civil, Imobiliário, Agrário e Empresarial. São Paulo: Ed. Revista dos Tribunais, ano 5, janeiro/ março 1981.

MINISTÉRIO DE INTERIOR. Notas sobre os problemas fundiários urbanos. Seminário sobre problemas fundiários urbanos. Brasília, agosto 1980.

. Desenvolvimento Urbano, Projeto de Lei Federal $n^{\circ}$ 775/83, Brasília, 1983.

MOREIRA, Antonio Cláudio Moreira Lima; Clementina De Ambrosis; Dalmo do Valle Nogueira Filho; Domingos Theodoro Azevedo Netto. O Solo Criado. São Paulo: Centro de Estudos e Pesquisas de Administração Municipal CEPAM, 1975.
MOREIRA, Antônio Cláudio M. L. O entesouramento em terrenos urbanos. C. J. 
Arquitetura, Revista de Arquitetura, planejamento e construção, $\mathrm{n}^{\circ}$ 16. São Paulo: FC Editora, 1977.

OLIVEIRA, Maria Teresa Corrêa. Multisectoral Partnerships for low income land development. Tese de doutorado, Universidade de Utrecht, Utrecht, 2002.

PESSOA, Álvaro. Equacionando a nova propriedade urbana. In: PESSOA, Álvaro (org.). Direito do urbanismo, uma visão sócio-jurídica. Rio de Janeiro: Instituto de Administração Municipal - IBAM, 1981.

PREFEITURA DA CIDADE DO RIO DE JANEIRO. Síntese do Seminário Solo Criado, seu impacto na dinâmica urbana e os desafios para sua operacionalização. Secretaria Municipal de Urbanismo e Meio ambiente, novembro de 1992.

PREFEITURA DO MUNICÍPIO DE SÃO BERNARDO DO CAMPO. A proposta de São Bernardo do Campo. C. J. Arquitetura, Revista de Arquitetura, planejamento e construção, $\mathrm{n}^{\circ}$ 16. São Paulo: FC Editora, 1977.

PREFEITURA DO MUNICÍPIO DE SÃO PAULO. A segunda proposta de São Paulo. $C$. J. Arquitetura, Revista de Arquitetura, planejamento e construção, $\mathrm{n}^{\circ}$ 16. São Paulo: FC Editora, 1977.

RABELLO, Sônia. A outorga do direito de construir e o plano diretor. 2005. (mimeo)

RENARD, Vincent. "Les outils de la politique foncière". In Droit de l'urbanisme, bilan et perspectives, Ajda L'actualité juridique, mai 1993.
REZENDE, Vera L. F. M. Planejamento $e$ Política Fundiária: o caso da cidade do Rio de 
Janeiro. Tese de Doutorado, FAUUSP, São Paulo, 1995.

RIBEIRO, Luiz Cesar de Queiroz. e Adauto L. Cardoso (Orgs.). Reforma Urbana e Gestão Democrática. Rio de Janeiro: Revan, FASE, 2003.

RIBEIRO, Luiz Cesar de Queiroz. (coord.) et alii. Questão urbana, desigualdades sociais $e$ políticas públicas: avaliação do programa nacional de reforma urbana. Rio de Janeiro: IPPUR/FASE, 1994.

RIBEIRO, Luiz Cesar de Queiroz e Orlando dos S. Júnior (org.). Globalização, fragmentação e reforma urbana. Civilização Brasileira, Rio de Janeiro, 1994.

RIBEIRO, Luiz Cesar de Queiroz. et alli. Reforma Urbana e Gestão das Cidades: Uma análise das Leis Orgânicas Municipais no Brasil. Trabalho apresentado no Seminário Internacional "Avaliação dos Instrumentos de Intervenção Urbana”. São Paulo: FAU/USP, 1993.

RIBEIRO, Luiz Cesar de Queiroz e Cardoso, Adauto. O Solo Criado como Instrumento da Reforma Urbana. Revista de Administração Municipal, vol.39, n²03, p.36-47, abr/jun 1992. Rio de Janeiro: IBAM, 1992.

RIBEIRO, Luiz Cesar de Queiroz. e Cardoso, A. L.. O solo criado como instrumento de reforma urbana: avaliação de seu impacto na dinâmica urbana. Cadernos IPPPUR UFRJ, ano v, no $1, \operatorname{dez} 1991$.

ROCHA LAGOA, Paulo. O projeto de lei sobre desenvolvimento urbano, algumas considerações. Rio de Janeiro, 1984. (mimeo) 
ROLNIK, Raquel e Renato Cymbalista (Orgs.). Instrumentos urbanísticos contra a Exclusão Social. São Paulo: Pólis, 1997.

ROLNIK, Raquel. Planejamento urbano nos anos 90: novas perspectivas para velhos temas In RIBEIRO, Luiz Cesar de Queiroz e Orlando dos Santos Júnior (orgs.). Globalização, fragmentação e reforma urbana. Rio de Janeiro: Civilização Brasileira, 1994.

SCHERER, Rebeca. Plano Diretor de São Paulo: a relação entre projeto político e proposta técnica. In Plano diretor de São Paulo em questão, reflexão, alternativas. Boletim Técnico no 3. São Paulo: FAUUSP, 1992.

SEABRA FAGUNDES, Miguel. Aspectos jurídicos do solo criado. C. J. Arquitetura, Revista de Arquitetura, planejamento $e$ construção, no 16. São Paulo: FC Editora, 1977.

SETÚBAL, Olavo. Uma política para utilização do solo urbano. C. J. Arquitetura, Revista de Arquitetura, planejamento e construção, $\mathrm{n}^{\circ} 16$. São Paulo: FC Editora, 1977.

SILVA, Ana Amélia e Nelson Saule Junior. A cidade faz a sua constituição. São Paulo: Polis, 1993.

SILVA CORDEIRO, Iolene Marques. O clube urbano. C. J. Arquitetura, Revista de Arquitetura, planejamento e construção, $\mathrm{n}^{\circ} 16$. São Paulo: FC Editora, 1977.

SILVA, José Afonso da. Direito Urbanístico Brasileiro. São Paulo: Revista dos Tribunais, 1981.

SMOLKA, Martim O. Solo Criado: Notas para a Fundamentação de Questões em Debate.
Revista de Administração Municipal (RAM), n. 201, out/dez. 1991. 
SMOLKA, Martim O. e Fernanda Furtado (Eds.) Recuperación de Plusvalías en América Latina: alternativas para el desarrollo urbano. Pontifícia Universidad Católica de Chile y Lincoln Institute of Land Policy, Colección Eurelibros, Santiago, Chile, 2001.

SOMEKH, Nadia. O plano diretor de São Paulo e o Solo Criado. Seminário Solo Criado, seu impacto na dinâmica urbana e os desafios para sua operacionalização, Prefeitura da Cidade do Rio de Janeiro. Rio de Janeiro, novembro 1992a.

Plano Diretor de São Paulo: uma aplicação das propostas de solo criado. In RIBEIRO, L. C. de Q. e LAGO, L. C. (orgs.)

Acumulação urbana e a cidade. Rio de Janeiro: IPPUR/UFRJ, $1992 \mathrm{~b}$.

VILLA, Bona de. O controle do Uso e da Ocupação do Solo Urbano pelo Município. São Paulo: Fundação Prefeito Faria Lima CEPAM, 2001. 